\title{
Reforming Competence Restoration Statutes: An Outpatient Model
}

Susan A. McMahon

Georgetown University Law Center, sam56@law.georgetown.edu

This paper can be downloaded free of charge from:

https://scholarship.law.georgetown.edu/facpub/2180

https://ssrn.com/abstract=3132700

Georgetown Law Journal, Vol. 107, Issue 3, 601-645.

This open-access article is brought to you by the Georgetown Law Library. Posted with permission of the author. Follow this and additional works at: https://scholarship.law.georgetown.edu/facpub

Part of the Criminal Procedure Commons, Disability Law Commons, and the Law and Society Commons 


\title{
Reforming Competence Restoration Statutes: An Outpatient Model
}

\author{
SUSAN MCMAHON*
}

Defendants found incompetent to stand trial are often committed to an inpatient mental health facility to restore their competence, even if outpatient care may be the better treatment option. This inpatient-default model has two serious negative effects: (1) defendants found incompetent spend far longer confined before trial than their similarly situated competent counterparts, and (2) because of long wait periods for hospital beds, defendants found incompetent spend large chunks of their time confined in a jail cell, which is possibly the worst place for a person with a mental health condition to be housed.

This Article is the first to examine how the language of competence restoration statutes defaults to inpatient treatment, even when the statute appears to allow for outpatient care. Some statutes mandate inpatient care. Others impose additional, irrelevant hurdles to the release of defendants found incompetent, or give courts unbridled discretion to place defendants in inpatient care, or both. When paired with widespread false presumptions about individuals living with mental illness, the implicit-or sometimes explicit-inpatient default found in most competence restoration statutes leads courts to overcommit defendants to state mental health facilities.

This Article proposes amendments to the statutory language that will require judges to place defendants in outpatient care, unless specific criteria justify inpatient treatment. Such a change would accomplish two goals. First, it would eliminate the needless disparity in pretrial confinement between defendants found incompetent and those found competent. Although the rates of pretrial confinement will almost certainly remain higher among defendants found incompetent, that confinement would be based on criteria related to the defendant's treatment need, not biased concerns about the defendant's perceived dangerousness. Second, an outpatient-default model would relieve pressure on inpatient facilities, opening up space for those who truly need inpatient treatment to restore competence. When the competence restoration backlog is alleviated, defendants who need inpatient care

* Professor of Law, Legal Practice, Georgetown University Law Center. (C) 2019, Susan McMahon. This Article would not have been possible without the wise advice of Erin Carroll, Joan Goldfrank, Michael Perlin, Jeffrey Shulman, Rima Sirota, Tom Spoth, and the participants in the GULC Legal Writing Scholarship Workshop and the GULC Summer Workshop Series. Special thanks also to Matthew Hofer and Christine LiCalzi for excellent research assistance and to the Georgetown University Law Center for its support. 
will be transferred to hospitals immediately, rather than waiting for months in a jail cell until a bed opens up.

\section{TABLE OF CONTENTS}

INTRODUCTION

I. Competence Restoration Process and Problems

A. DEFENDANTS FOUND INCOMPETENT TO STAND TRIAL SPEND LONGER PERIODS IMPRISONED THAN COMPETENT DEFENDANTS.

B. DEFENDANTS LIVING WITH MENTAL ILLNESS SUFFER SIGNIFICANT HARMS WHILE CONFINED.

1. Jail Environment and Services................ 613

2. Solitary Confinement ................... 614

3. Abuse and Neglect ................... 615

II. The Stigma Against Individuals with Mental Health Conditions 617

A. DANGEROUSNESS .............................. 618

B. NECESSITY OF HOSPITALIZATION . . . . . . . . . . . . . . . . . . 620

III. The Law of Competence. . . . . . . . . . . . . . . . . . . . . . . . . 624

A. COMPETENCE IN COMMON LAW AND CONSTITUTIONAL LAW ....... 625

B. COMPETENCE RESTORATION STATUTES ................... 627

1. Required Inpatient Statutes . . . . . . . . . . . . . 628

2. Discretionary Inpatient Statutes............. 630

a. No Guidance on Placement of Defendant ........ 631

b. Ineffective Criteria for Placement of Defendant .... 633

IV. An Outpatient Competence Restoration Model ............... 636

A. ELIMINATING PRETRIAL RELEASE DiSPARITIES .............. 638

B. IMPOSING CONCRETE CRITERIA FOR INPATIENT TREATMENT ...... 639

C. CRITIQUES OF PROPOSED COMPETENCE RESTORATION REGIME. ..... 640

1. These Are Not Really Rules . . . . . . . . . . . . . . 641

2. No Legislature Would Pass These Amendments ...... 642 
3. There Are Better Alternatives .............

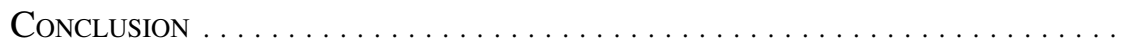

\section{INTRODUCTION}

Police arrested Jamycheal Mitchell for stealing five dollars' worth of snacks at a 7-Eleven. ${ }^{1}$ A judge found him incompetent to stand trial and ordered him sent to a state mental health facility to restore his competence. ${ }^{2}$ Four months later, he died in his jail cell, forty pounds lighter than he was when arrested, after prison officials allegedly denied him food, turned off the water to his cell, and failed to provide him with medications to treat his mental illness. ${ }^{3}$ Mitchell was never admitted to the mental health facility. ${ }^{4}$

A Texas judge found Isaac Lemelle incompetent in March 2016. ${ }^{5}$ Almost six months later, he was still waiting for a transfer to a mental health facility. ${ }^{6}$ A class action lawsuit filed in Texas alleged that 346 other defendants were in similar straits: confined to a jail or prison, but waiting for space to open at an inpatient facility. ${ }^{7}$ For most of his six-month wait, Lemelle was confined to the jail's psychiatric lockdown unit, where he was allowed out of his cell for only one hour per day and had no guaranteed time outdoors. ${ }^{8}$

After John Sherman was found incompetent to stand trial, the examining psychiatrist recommended outpatient treatment, which the court and the prosecutor agreed was "best for all concerned." If institutionalized, Sherman risked permanent harm. ${ }^{10}$ Regardless, believing itself bound by the language of the statute governing competence restoration, the court committed Sherman to the custody of the Attorney General, who was required to hospitalize the defendant. ${ }^{11}$

These stories are not uncommon. Defendants who live with mental illness and are found incompetent to stand trial are often ordered committed to an inpatient mental health facility to restore their competence, even if outpatient care may be the better treatment option. Rather than receive treatment in the community, defendants are usually sent to a state psychiatric hospital and confined throughout

1. Complaint at 5, Adams v. Naphcare, Inc., 246 F. Supp. 3d 1128 (E.D. Va. 2017) (No. 2:16-cv-

229), aff 'd in part, rev'd in part sub nom. Adams v. Ferguson, 884 F.3d 219 (4th Cir. 2018).

2. Id.

3. Id. at 6-7.

4. Id. at 5 .

5. Third Amended Complaint for Injunctive and Declaratory Relief at 5, Ward ex rel. Bourliot v. Hellerstedt, No. 1:16-cv-00917 (W.D. Tex. Sept. 29, 2017).

6. Id. at 6 .

7. Id. at $9-10$.

8. Id. at 23 .

9. United States v. Sherman, 722 F. Supp. 504, 505 (N.D. Ill. 1989).

10. Id.

11. Id. at 505-06 (noting that the court had no power to order placement of defendant, but recommending that the Attorney General consider "hospitalize in a suitable facility" to mean giving the defendant the treatment he needed to become competent). 
their treatment. ${ }^{12}$ Not only are they confined during their care, but they also spend long periods of time in jail as they wait for a hospital bed to become available. ${ }^{13}$ These individuals have not been convicted of a crime, yet they spend weeks or months under state control-in either jail or a psychiatric institution-before their trial can even begin.

This default to inpatient care is problematic on two fronts. First, defendants found incompetent to stand trial spend much more time in pretrial detention than competent defendants accused of the same offense. ${ }^{14}$ This is true even if the defendants have the same charge severity and pose the same risk of re-arrest if released before trial. ${ }^{15}$ Second, defendants spend much of that confinement in their jail cell (waiting for an inpatient bed to open up), even though individuals living with a mental health condition are particularly unsuited for the jail environment. Such defendants are placed in solitary confinement at higher rates, experience neglect and abuse from fellow prisoners and guards, and descend further into mental illness when confined without treatment. ${ }^{16}$ As criminal justice systems move toward reforming pretrial detention - in part because of the recognition that it causes deep harm to individuals, families, and communities ${ }^{17}$ - the individuals living with mental illness who are most harmed by those conditions remain stuck in limbo between a jail cell and a hospital bed.

Outpatient competence restoration programs promise to relieve this pressure. A handful of jurisdictions have experimented with outpatient programs for small numbers of defendants. ${ }^{18}$ Those efforts have been mostly successful,

12. See, e.g., Bruce J. Winick, Restructuring Competency to Stand Trial, 32 UCLA L. REV. 921,933 (1985) ("Of those defendants found incompetent, the overwhelming majority are committed to state hospitals for treatment.").

13. See infra Part I.

14. See infra Section I.A.

15. Id.

16. See infra Section I.B.

17. See, e.g., Pretrial Justice Inst., The State of Pretrial Justice in America 3 (2017), https:// university.pretrial.org/HigherLogic/System/DownloadDocumentFile.ashx?DocumentFileKey=f9d452f6ac5a-b8e7-5d68-0969abd2cc82\&forceDialog=0 [https://perma.cc/YRD7-DEKU] ("The past five years have witnessed a remarkable growth in support for reforming our nation's pretrial justice system . . . . This unprecedented interest emerges from a growing awareness that existing pretrial operations lead to unnecessary detention of poor and working class people-disproportionately people of color-while those with money are able to go free with little or no supervision, regardless of any danger they may present.").

18. According to one recent report prepared for the State of Washington's Department of Social and Health Services, only fifteen states (and the District of Columbia) have formal outpatient competence restoration programs: Arkansas, Colorado, Connecticut, Florida, Georgia, Hawaii, Louisiana, Michigan, Nevada, Ohio, Rhode Island, Tennessee, Texas, Virginia, Washington, D.C., and Wisconsin. See Groundswell Servis., Inc., Forensic Mental Health Consultant Review Final Report 28 \& n.6 (2014), https://www.dshs.wa.gov/sites/default/files/BHSIA/WSH/GroundswellReport6.30.14.pdf [hereinafter WA REPORT]. Another recent report added two more states to this list: California and Oregon. See W. Neil Gowensmith et al., Lookin' for Beds in All the Wrong Places: Outpatient Competency Restoration as a Promising Approach to Modern Challenges, 22 PsYCHOL. PuB. POL'y \& L. 293, 299 tbl.4 (2016). Utah has also recently adopted an outpatient competence restoration program. See Press Release, Disability Law Ctr., Officials Sign Class Action Settlement Agreement to Reduce Wait Time for Those Needing Mental Health Services to Stand Trial (June 12, 2017), http://disabilitylawcenter.org/wp-content/uploads2/2017/ 
achieving restoration rates comparable to inpatient programs at a significantly lower cost. ${ }^{19}$

But even if every state suddenly opened a robust outpatient competence restoration program, an obstacle looms: the statutes governing competence restoration, which default to the inpatient-treatment model. Several states mandate inpatient restoration in their statutory schemes. ${ }^{20}$ The rest allow for outpatient restoration, but the language of these laws often preserves the inpatient default by requiring defendants to meet a series of nebulous or irrelevant criteria before allowing them to participate in outpatient treatment. ${ }^{21}$

Statutes without precisely focused criteria for assessing which defendants belong in inpatient treatment will inevitably lead to an overcommitment of individuals in hospitals because of the vast stigma surrounding mental illness. One deeply held myth is that people with mental illness are dangerous. Yet studies have shown that individuals with mental illness are no more violent than other individuals in similar circumstances. ${ }^{22}$ The public also believes that a hospital setting is almost always the best option for treatment, yet outpatient programs have been successful even for individuals suffering from severe mental illness. ${ }^{23}$ One scholar has termed these ideas "sanist" myths-assumptions based on widespread misunderstandings about mental illness. ${ }^{24}$ Judges are not immune from such biases and may actually be more susceptible to them because they play to a trial judge's worst fear: releasing a defendant before trial who then commits a violent crime. $^{25}$

This Article is the first to examine how the language of competence restoration statutes, even those that allow for outpatient treatment, defaults to commitment to an inpatient facility. Where these statutes do not outright mandate inpatient care, they give unbridled discretion to judges to hospitalize defendants. That discretion, paired with widespread false presumptions about individuals living with mental illness, leads to overcommitment. In addition, these statutes place hurdles in the path of defendants found incompetent that are both more stringent than those that must be met by competent defendants and irrelevant to the question of whether inpatient treatment is necessary for competence restoration.

I propose amendments to the statutory language that will require judges to place defendants in outpatient care, unless specific criteria justify inpatient

06/FY17-DHS-DLC-Settlement-Press-Release.pdf ("The parties agreed to continue the state's innovative community-based Outreach Program, started in 2016, which treats low-risk forensic patients in the community to lessen the wait time for a bed at the Hospital.").

19. Gowensmith et al., supra note 18, at 299 (noting estimated savings per outpatient referral of $\$ 21,409$ in Texas and $\$ 41,290$ in Wisconsin). One survey estimated outpatient treatment for competence restoration saved about $\$ 60,000$ per participant, as compared to inpatient treatment. WA REPORT, supra note 18 , at 29 .

20. See infra Section III.B.1.

21. See infra Section III.B.2.

22. See infra Section II.A.

23. See infra Section II.B.

24. See Michael L. Perlin, On “Sanism," 46 SMU L. Rev. 373, 375 (1992); see also infra Part II.

25. See infra Section II.A. 
treatment. My proposal suggests two major reforms. First, defendants found incompetent should be subject to the same pretrial release standards as other defendants. Competence restoration statutes should be stripped of additional irrelevant hurdles that apply only to defendants found incompetent; after all, questions of dangerousness or flight risk are already addressed by jurisdictions' pretrial release statutes. Second, the one criterion that competence restoration statutes should assess is whether inpatient treatment is the only avenue to successfully restore a defendant's competence. To effectively evaluate that question, statutes must default to outpatient treatment unless some specific conditions justify committing the defendant to an inpatient facility. Such a change would eliminate bars to outpatient placements and relieve pressure on inpatient facilities, thus opening up beds for those who cannot be restored elsewhere. It would also ensure that specific criteria relevant to treatment—not misunderstandings or fears about individuals living with mental illness-inform the decision to commit the defendant to inpatient care.

I make this case in four parts. Part I overviews the competence evaluation and restoration process and describes how overcrowding in inpatient facilities has left many defendants stranded in jails before competence restoration can begin. Part II describes the mistaken assumptions that push judges toward inpatient treatment. Part III explains the law governing competence restoration, describing the history of the doctrine and the statutes that currently determine competence restoration placement. Here, I show how these statutes leave much room for sanist impulses to govern decisionmaking. Finally, in Part IV, I advocate for a statute that cabins judicial discretion and defaults to an outpatient option.

Previous scholarship has tackled competency evaluations ${ }^{26}$ or reforming incompetence procedure generally. ${ }^{27}$ Yet little has been said about the role competence restoration statutes have played in driving huge numbers of defendants toward inpatient treatment, and thus toward extended jail detention. This Article begins to fill that gap by identifying those laws as a reason for the competence restoration backlog and proposing amendments to ease the flood of defendants referred for inpatient competence restoration. ${ }^{28}$

26. See, e.g., Gowensmith et al., supra note 18, at 293-94 (noting that the scholarship has a "robust focus" on competency to stand trial evaluations, but "less attention has been given to competency restoration"). See generally Grant H. Morris et al., Competency to Stand Trial on Trial, 4 Hous. J. HEAlth L. \& POL'Y 193 (2004) (considering the legal standards for competence to stand trial and finding that mental health professionals who conduct competency evaluations rarely understand those standards).

27. See, e.g., Robert A. Burt \& Norval Morris, A Proposal for the Abolition of the Incompetency Plea, 40 U. CHI. L. REv. 66, 75 (1972); Bruce J. Winick, Reforming Incompetency to Stand Trial and Plead Guilty: A Restated Proposal and a Response to Professor Bonnie, 85 J. CRIM. L. \& CRIMINOLOGY 571, 573, 582-96 (1995) [hereinafter Winick, Reforming Incompetency]; Winick, supra note 12, at 92728, 951-79.

28. Before diving in, a word about what this Article aims to accomplish. Defendants living with mental disorders face a myriad of issues as they navigate the criminal justice system. For example, they tend to be homeless and live in poverty, which raises obstacles to pretrial release, such as an inability to pay bail. I recognize that my proposed amendments will not solve these difficult related issues. That 


\section{Competence Restoration Process and Problems}

A defendant in a criminal case-let's call him Marty—yells at the judge and spits on the floor during his first appearance in court after his arrest. Marty has a history of schizophrenia, which first manifested as auditory hallucinations when he was seventeen. He is now twenty-three and homeless, and has been accused of criminal trespass because he set up his tent on private property for one night.

After the outburst in court, the judge suspects that Marty might not be competent to stand trial. The judge knows the legal standard for competence- a defendant must be able to consult with his attorney with a reasonable degree of rational understanding and must have both a factual and rational understanding of the proceedings against him ${ }^{29}$ - but he does not yet know the scope of the issue. Plenty of individuals with mental health conditions have enough of a grasp on reality to communicate with their attorney and understand the proceedings, ${ }^{30}$ the judge thinks. He needs an expert to help him decide whether Marty clears the competence bar, and he orders a competency assessment. ${ }^{31}$

The above hypothetical is typical of the first stage of the competence process, competency evaluation. Between 50,000 and 60,000 defendants are referred for competency assessments each year. ${ }^{32}$ If the defendant is found incompetent, as about 10,000 to 12,000 defendants are annually, then the second stage of the competence process - competence restoration, the focus of this Article—-begins. ${ }^{33}$

said, even if state legislatures eliminated bail bonds and eradicated homelessness, competence restoration statutes would remain obstacles to placing defendants found incompetent in outpatient treatment. Amendment of these provisions is thus a necessary piece, but not the only piece, of any plan to tackle the issues facing defendants with mental health diagnoses in the criminal justice system.

29. See Dusky v. United States, 362 U.S. 402, 402 (1960).

30. See, e.g., Curt R. Bartol \& Anne M. Bartol, Psychology and Law: Research And PRACTICE 105 (2015) (indicating competency is found in eighty percent of competency assessments); Janet I. Warren et al., Factors Influencing 2,260 Opinions of Defendants' Restorability to Adjudicative Competency, 19 PSYCHOL. PUB. POL'Y \& L. 498, 498 (2013) (indicating about twenty to thirty percent of individuals assessed for competency are found incompetent).

31. Although this hypothetical describes how the process would usually work in practice, many scholars have raised questions as to the appropriateness of relying on expert testimony in assessing competence. One study concluded that mental health professionals can be unreliable because they often conflate the competency assessment with clinical issues, such as whether the defendant has a serious mental disorder, e.g., Morris et al., supra note 26, at 237, while other scholars believe lawyers and judges are better at assessing competence than clinicians, e.g., Winick, Reforming Incompetency, supra note 27, at 612 ("Competence to stand trial is fundamentally a legal question. A lawyer is better able than a clinical evaluator to determine whether a client possesses the skills needed to participate in a criminal trial.").

32. See, e.g., BARTOL \& BARTOL, supra note 30, at 105; Douglas Mossman et al., AAPL Practice Guideline for the Forensic Psychiatric Evaluation of Competence to Stand Trial, 35 J. AM. ACAD. PSYCHIATRY \& L. S3, S3 (2007); Warren et al., supra note 30, at 498.

33. Some scholars suspect that both categories of defendants, those evaluated and those found incompetent, have grown substantially since these estimates were calculated in 2000. E.g., Gowensmith et al., supra note 18, at 293 ("Moreover, the number of evaluations is growing annually. The state of Colorado reported a $206 \%$ increase in the number of CST evaluations from 2005 to 2014, whereas Los Angeles County reported a 273\% increase from 2010 to 2015." (citations omitted)); id. at 295 ("Hawaii saw a $35.8 \%$ increase in persons found [incompetent to stand trial] from 2005 to 2009 , Wisconsin had a $34.8 \%$ increase between 2011 and 2013, and Washington saw a 73\% increase between 2010 and 2014." 
Here is how that process typically works: After a finding of incompetence, a court orders Marty sent to a state mental health facility. There, mental health professionals will attempt to both treat his schizophrenia with antipsychotic medication and give him some tools to help him communicate with his attorney and understand the criminal trial. ${ }^{34}$

The first priority is to bring Marty's symptoms under control. Treatment for psychotic disorders such as schizophrenia will include antipsychotic medications, ${ }^{35}$ which should begin to ease his hallucinations immediately, with further improvements continuing over the next six to eight weeks. ${ }^{36}$ Although the drugs usually do not achieve total remission of symptoms, about eighty-seven percent of individuals improve to the point of becoming competent to stand trial. ${ }^{37}$

Once the medication begins working, Marty may then be placed in an education program. ${ }^{38}$ A typical program would familiarize Marty with legal concepts and trial processes, such as the roles of various courtroom personnel and information about criminal charges and pleas. ${ }^{39}$ He may take part in a mock trial, watch a movie depicting courtroom scenes, or hear from a defense attorney about what to expect in court. ${ }^{40} \mathrm{He}$ may also learn anxiety-reducing techniques to calm himself during the proceeding. ${ }^{41}$

The goal with competence restoration is not the same as if Marty were seeking psychiatric care as a patient. To be competent is not to be well or even symptomfree. One can engage in delusional thinking or hear and see things that are not there, and still be able to communicate with an attorney and understand the proceedings. Competence restoration success rates are therefore typically high and

(citations omitted)); see also BARTOL \& BARTOL, supra note 30, at 105 (suggesting competency evaluations have grown steadily alongside arrest rates).

34. See Debra A. Pinals, Where Two Roads Meet: Restoration of Competence to Stand Trial from a Clinical Perspective, 31 New Eng. J. ON CRIM. \& Civ. ConfinEmENT 81, 88 (2005) (noting that although almost all competence restoration programs relied on medication to restore the competence of defendants with mental illness, a significant sub-set of programs studied—eighty-eight percent—also used some type of didactic or psychoeducational group intervention).

35. See id. at 89 (describing antipsychotic medication as part of "the usual treatment approach").

36. Robert Freedman, Schizophrenia, 349 NEw ENG. J. MED. 1738, 1742 (2003).

37. Brian Ladds et al., Involuntary Medication of Patients Who Are Incompetent to Stand Trial: A Descriptive Study of the New York Experience with Judicial Review, 21 BULl. AM. ACAD. PSYCHIATRY L. 529, 539 (1993) (describing the results of a study conducted between 1986 and 1990).

38. One constant across almost all competence restoration programs is antipsychotic medication for those who suffer from psychotic disorders. See Pinals, supra note 34 , at 88 . But whether the hospital also has an education component and, if so, what that program looks like, varies widely from institution to institution. Few studies have looked to the effectiveness of these programs, but the case studies described in the sources mentioned in notes 34 and 36 provide some indication that medication-pluseducation programs enjoy high rates of success in restoring defendants to competence.

39. See Pinals, supra note 34, at 89-93; see also Stephen G. Noffsinger, Restoration to Competency Practice Guidelines, 45 InT'L J. OfFender TherAPy \& COMP. CRIMINOLOGY 356, 357 (2001) (discussing the need to teach defendants about legal concepts and the criminal trial process as part of competency restoration).

40. Noffsinger, supra note 39, at 359-60.

41. Id. at 361 . 
defendants are returned to court within a few months, their competence restored. ${ }^{42}$

The problem is that not enough public psychiatric beds exist to accommodate the defendants referred for competence restoration each year. Public hospital facilities nationwide have only about 38,000 staffed beds, or 11.7 beds per 100,000 people. ${ }^{43}$ According to health policy experts, 40 to 60 beds per 100,000 people are necessary to meet the demand for inpatient care. ${ }^{44}$

Of the 38,000 beds available, only about 17,000 are reserved for forensic patients, meaning patients who have come into contact with the criminal justice system in some way. ${ }^{45}$ Those 17,000 beds must accommodate both the defendants found incompetent to stand trial every year and the longer term residents of mental health facilities, such as convicted offenders with a mental health condition, inmates found not guilty by reason of insanity, or sexually violent predators. One survey of mental health directors showed that in 2016 alone, at least 21,091 individuals were referred for forensic services at state hospitals; that number includes neither the states who did not respond to the survey nor longer term residents of state mental health facilities who already occupied forensic beds. ${ }^{46}$ There are simply not enough inpatient beds to go around, and defendants found incompetent to stand trial are often put in the back of the line. ${ }^{47}$

The result of the inpatient bed shortage is lengthy wait times for competence restoration services. In 2012, California's waitlist was commonly 200 to 300 defendants long. ${ }^{48}$ In 2010 , the average wait time was 68 days, or over two months, with some inmates waiting as long as 162 days, or over five months. ${ }^{49}$ One recent lawsuit in Texas revealed that an average of 306 pretrial defendants were waiting for a bed to open at a state psychiatric facility at any given time in $2011 .^{50}$ These detainees waited in county jail for as long as seven months before their transfer to a state mental hospital. ${ }^{51}$ In 2006, Florida's waitlist stood at 310

42. See Gowensmith et al., supra note 18, at 301 ("Nationally, inpatient lengths of stay for individuals who are restored to competency average around 89 days ...."); Warren et al., supra note 30, at 499 (analyzing studies finding upwards of seventy percent restoration rates and concluding that "incompetent defendants are overwhelmingly restored to competency").

43. Doris A. Fuller et al., Treatment Advocacy Ctr.: Office of Research \& Pub. Affairs, Going, Going, Gone: Trends and Consequences of Eliminating State Psychiatric Beds 1 (2016).

44. Id. at 3 .

45. Id. at 1 .

46. See Amanda Wik et al., Nat'l Ass'n of State Mental Health Program Dirs., Forensic Patients in State Psychiatric Hospitals: 1996-2016, at 82-83 (2017), https://www.nasmhpd.org/ sites/default/files/TACPaper.10.Forensic-Patients-in-State-Hospitals_508C_v2.pdf.

47. In California, for example, the Department of Mental Health prioritizes finding beds for convicted offenders, individuals found not guilty by reason of insanity, and sexually violent predators over defendants found incompetent to stand trial. MAC TAYLOR, LEGISLATIVE ANALYST'S OfFICE, AN Alternative Approach: Treating the InCOMPETEnT to StAnd Trial 10 (2012), http://www.lao.ca. gov/reports/2012/hlth/ist/incompetent-stand-trial-010312.pdf.

48. Id. at 9.

49. Id. at 8-9.

50. Lakey v. Taylor, 435 S.W.3d 309, 314 (Tex. App. 2014).

51. Id. 
defendants. ${ }^{52}$ One Florida defendant awaiting hospital placement was held in an isolation cell at the jail for two months, refusing to eat meals served to him because he believed they were poisoned. ${ }^{53}$ The statistics in other states are equally dire. A survey of forty states found that thirty-one had waitlists, with average wait times of one month for criminal defendants to get hospital beds. ${ }^{54}$ Three states had average wait times of six months to one year. ${ }^{55}$

These lengthy wait times are troubling on at least two different fronts: (1) defendants found incompetent to stand trial are imprisoned for longer periods of time than competent defendants, and (2) defendants living with mental illness suffer significant harm while in jail. ${ }^{56}$

\section{A. DEFENDANTS FOUND INCOMPETENT TO STAND TRIAL SPEND LONGER PERIODS IMPRISONED THAN COMPETENT DEFENDANTS}

A defendant who is found incompetent to stand trial and is hospitalized will often spend a longer time imprisoned than a competent defendant accused of the same crime with the same criminal history. ${ }^{57}$ One study of criminal defendants in New York City found that defendants diagnosed with a mental health condition ordinarily stayed in jail twice as long as defendants without mental illness, even though these two groups had the same charge severity and risk of re-arrest. ${ }^{58}$ In New Mexico, defendants without mental health conditions were held in detention facilities for an average of 141 days. ${ }^{59}$ Defendants who had competency hearings and were found competent were held in those facilities for 332 days. ${ }^{60}$ Defendants found incompetent were held for 537 days, over a year longer than

52. Dep’t of Children \& Families v. Soliman, 947 So. 2d 568, 569 (Fla. Dist. Ct. App. 2006).

53. Id.

54. W. Lawrence Fitch, Nat'l Ass'n of State Mental Health Program Dirs., Forensic Mental Health Services in the United States: 2014, at 30 (2014).

55. Id.

56. This Article focuses on only the harms defendants may suffer while detained; there are likely long-lasting adverse behavioral and psychological consequences as well. The theory of therapeutic jurisprudence suggests that policymakers and academics should also consider these often-hidden consequences when assessing a law. See Bruce J. Winick, The Side Effects of Incompetency Labeling and the Implications for Mental Health Law, in LAw IN A THERAPEUTIC KeY: DeVELOPMENTS IN Therapeutic Jurisprudence 17, 17-18 (David B. Wexler \& Bruce J. Winick eds., 1996). Bruce Winick has persuasively argued that even the labeling of an individual as incompetent-regardless of what happens to that individual after this finding-has negative psychological effects that are rarely considered in the justification of laws requiring competence. Id. at 19-20.

57. See, e.g., Winick, Reforming Incompetency, supra note 27, at 580 ("If convicted, many of these [misdemeanor] defendants would pay a small fine or receive a period of probation. Instead, they might spend months or years confined as incompetent.").

58. The Council of State Gov'ts Justice Ctr., Improving Outcomes for People with Mental Illnesses Involved with New York City's CRiminal Court and Correction Systems 3 (2012), https://csgjusticecenter.org/wp-content/uploads/2013/05/CTBNYC-Court-Jail_7-cc.pdf.

59. LiNDA FREEMAN ET AL., N.M. SENTENCING COMM'N, EFFECT OF COMPETENCY AND DiagnOSTIC Evaluation on Length of Stay in a SAmple of New Mexico Detention Facilities 3 (2013), https://nmsc.unm.edu/reports/2013/effect-of-competency-and-diagnostic-evaluation-on-length-of-stayin-a-sample-of-new-mexico-detention-facilities.pdf.

60. Id. 
arrestees without mental health conditions. ${ }^{61}$

These numbers can vary significantly depending on the defendant. Medication takes longer to work in some patients than others, and doctors may attempt a series of medications (each of which can take up to two months to show results) before finding one that works. ${ }^{62}$ And antipsychotics are not a panacea-for about twenty percent of patients, they never work. ${ }^{63}$

Moreover, defendants rendered competent in a state mental health facility often fall back into incompetence when returned to local jails to resume trial proceedings. Defendants who have been restored to competence through antipsychotic medication may refuse to continue taking the medication when they return to their jail cell, or the jail may not have the same medications available as the inpatient facility. ${ }^{64}$ Psychotic symptoms may quickly return. The result is an endless loop of defendants restored to competence, returned for trial, found incompetent, and again returned to the system for competence restoration. ${ }^{65} \mathrm{In}$ a single year in Florida, for example, $7.8 \%$ of defendants restored to competence and transported to jail pending trial were returned to a competence restoration facility before the trial could begin. ${ }^{66}$ One man with schizophrenia in Texas spent over a year and a half bouncing between jail cells and the state

61. Id.

62. See, e.g., Dora W. Klein, The Costs of Delay: Incompetent Criminal Defendants, Involuntary Antipsychotic Medications, and the Question of Who Decides, 16 U. PA. J.L. \& Soc. Change 203, 209 (2013) ("It is a well-documented fact that it is generally not possible to predict how a particular person will respond to a particular antipsychotic medication. For treating physicians, this means that finding a medication that is effective in alleviating the symptoms of psychosis but does not cause side effects that are intolerable is an exercise in trial and error." (footnote omitted)); Susan A. McMahon, It Doesn't Pass the Sell Test: Focusing on "the Facts of the Individual Case" in Involuntary Medication Inquiries, 50 AM. CRIM. L. REv. 387, 393 (2013) (stating that antipsychotics usually have a partial effect immediately, with the full impact of the medication taking place over six to eight weeks).

63. E.g., William M. Brooks, Reevaluating Substantive Due Process as a Source of Protection for Psychiatric Patients to Refuse Drugs, 31 InD. L. REV. 937, 946 (1998).

64. See Fla. Senate Budget Subcomm. on Health \& Human Servs. Appropriations, Interim Report on the Forensic Mental Health System, at 3 (2011) ("Reasons for [decompensation] include delays in the trial date, differences in the drug formulary between the state treatment facility and the jail, the mental fragility of the individual, and disagreements between the court-ordered competency evaluation and the forensic hospital's evaluation.”) [hereinafter FLA. SENATE REPORT]; Michael Braga et al., Insane. Invisible. In Danger. 'Definition of Insanity': Florida Spends Millions Making Sure the Mentally Ill Go To Court-And Gets Nothing for It, TAMPA BAY TIMES (Dec. 18, 2015), http://www. tampabay.com/projects/2015/investigations/florida-mental-health-hospitals/competency/ [https://perma. cc/YH78-HCG7] ("Florida does little to make sure patients who are successfully treated stay competentnot even long enough to face their day in court."); Ben Hattem, How New York's Mentally Ill Get Lost in Courts, Jails and Hospitals, AL JAZEERA AM. (July 27, 2015, 5:30 AM), http://america.aljazeera.com/ articles/2015/7/27/ny-mentally-ill-get-lost-in-the-justice-system.html [https://perma.cc/NCW2-E2ET] ("[P] eople who have attained competency in the state's mental hospitals frequently decompensate while waiting to appear in court, bouncing back and forth between psychiatric facilities and Rikers Island sometimes for years without trial.").

65. See Braga et al., supra note 64; Hattem, supra note 64.

66. Fla. SenAte Report, supra note 64, at 3 (assessing statistics for competence restoration recidivism in fiscal year 2010-11). 
mental hospital. ${ }^{67}$

Notably, this all assumes that the defendant is a willing participant in his competence restoration. When defendants refuse medication at the treatment facility, pretrial detentions can extend even longer. It is not uncommon for defendants in federal courts to have been detained for well over a year before a court decides a motion to medicate. ${ }^{68}$ For cases that continue on to the appellate courts, the wait can be two to three years between indictment and decision on the motion to medicate. ${ }^{69}$

The case of Herbert Evans provides but one example of the long path between indictment, competence restoration, and verdict. ${ }^{70}$ After being indicted for threatening a government agent in November 2002, he remained in pretrial detention for the next four years and was dosed with antipsychotic medication against his will. $^{71}$ In November 2007, a jury acquitted him of all charges. ${ }^{72}$

Defendants like Evans who are found incompetent to stand trial will need to spend more time in contact with the criminal justice system, simply because they go through a competence restoration process that is inapplicable to other defendants. The relevant question, however, is whether the defendant spends that time in a state facility or in the community. This Article does not challenge either the idea that these defendants should be treated differently or the notion that some subset of defendants found incompetent must be restored at an inpatient facility, and thus will spend a longer time in pretrial detention. What I instead argue is that competence restoration statutes as written send defendants to inpatient facilities on the basis of ambiguous and irrelevant criteria such as "dangerousness" rather than on the likelihood that inpatient treatment is necessary to restore competence. As a result, defendants found incompetent may be detained unnecessarily, enduring an involuntary separation from their communities and contributing to the backlog for inpatient beds.

67. Mitch Mitchell, Insane System? Arlington Man Bounces Between Jail, State Hospital, FoRT WORTh StAR-Telegram (May 9, 2016, 4:23 PM), http://www.star-telegram.com/news/local/ community/arlington/article76594692.html [https://perma.cc/4RRR-CMKJ].

68. See, e.g., United States v. Sherman, 2006 WL 1127006, at*1 (D. Ariz. Apr. 27, 2006) (indicted May 2, 2004; decision issued April 27, 2006); United States v. Horton, 941 F. Supp. 2d 843, 846 (N.D. Ohio 2013) (indicted August 18, 2011; decision issued April 22, 2013); United States v. Banks, 2015 WL 1932928, at*1 (W.D. Va. Apr. 29, 2015) (indicted November 18, 2013; decision issued April 29, 2015).

69. See, e.g., United States v. White, 620 F.3d 401, 414 (4th Cir. 2010) (defendant detained for fortyone months); United States v. Ruiz-Gaxiola, 623 F.3d 684, 694 (9th Cir. 2010) (defendant detained for over forty-seven months).

70. See United States v. Evans, 427 F. Supp. 2d 696 (W.D. Va.), aff'd, 199 F. App'x 290 (4th Cir. 2006).

71. Evans, 427 F. Supp. 2d at 697, 706; see also White, 620 F.3d at 418 (discussing the forcible medication of Evans).

72. Judgment of Acquittal at 1, United States v. Evans, No. 1:07-cr-00043 (W.D. Va. Nov. 15, 2007). 


\section{B. DEFENDANTS LIVING WITH MENTAL ILLNESS SUFFER SIGNIFICANT HARMS WHILE CONFINED}

Not only is lengthy pretrial detention problematic in its own right, but the jail environment is particularly harmful for inmates with mental illness because they (1) often deteriorate from a lack of treatment and exposure to a chaotic, violent environment; (2) are put in solitary confinement for rule infractions or psychiatric monitoring at higher rates than defendants without mental illness; and (3) suffer abuse and neglect at higher rates than defendants without mental illness.

\section{Jail Environment and Services}

While in jail, most defendants found incompetent to stand trial do not receive any competence restoration services. ${ }^{73}$ Often, they receive no mental health services whatsoever. ${ }^{74}$ Defendants with mental health conditions are known to quickly fall apart behind bars without adequate mental health treatment. One report on the conditions for detainees living with mental illness in Washington state jails found that individuals who had no access to mental health services "decompensated to the point of smearing themselves with feces, considering suicide, and experiencing hallucinations and extreme fear." $" 75$

The environment itself often contributes to the deterioration of these defendants. As one scholar succinctly put it, "[p]risons are places of intense brutality, violence, and dehumanization." 76 Inmates are tightly controlled and required to follow orders backed by force-forced to eat, sleep, and interact with others on terms dictated by jailers. ${ }^{77}$ Rape and violence are common occurrences. ${ }^{78}$ For an individual suffering from mental illness, this setting is "at best, counter-therapeutic and, at worst, dangerous to [an inmate's] mental and physical well being." $" 79$ These defendants have fewer resources to deal with the turmoil: "Anxious, depressed, psychotic[,] suicidal[,] and homicidal inmates are at increased risk of

73. See Lakey v. Taylor, 435 S.W.3d 309, 314 (Tex. App. 2014) (“[C]ounty jails do not provide competency-restoration treatment....").

74. One study found that only one in six jail inmates with mental illness received treatment after admission. Doris J. James \& Lauren E. Glaze, U.S. Dep'T of Justice, Bureau of Justice Statistics, Mental Health Problems of Prison and Jail InMates 1 (2006); see also Ram Subramanian et al., Vera Inst. of Justice, InCARCeration's Front Door: The Misuse of Jails in AMERica 12 (2015), http://www.safetyandjusticechallenge.org/wp-content/uploads/2015/01/incarcerations-front-door-report. pdf ("83 percent of jail inmates with mental illness did not receive mental health care after admission.").

75. Disability Rights Wash., Lost and Forgotten: Conditions of Confinement While WAITING FOR COMPETENCY EVALUATION AND RESTORATION 7 (2013).

76. Allegra M. McLeod, Prison Abolition and Grounded Justice, 62 UCLA L. REv. 1156, 1173 (2015).

77. E.g., id. at $1173-74$.

78. See id. at 1204 (explaining that there were approximately 216,000 sexual assaults in U.S. prisons in 2008).

79. Jamie Fellner, A Conundrum for Corrections, a Tragedy for Prisoners: Prisons as Facilities for the Mentally Ill, 22 WASH. U. J.L. \& POL'Y 135, 139 (2006); see also SUBRAMANIAN ET AL., supra note 74 , at 12 ("Characterized by constant noise, bright lights, an ever-changing population, and an atmosphere of threat and violence, most jails are unlikely to offer any respite for people with mental illness."). 
deteriorating emotionally and of having impaired judgment in such settings." 80

\section{Solitary Confinement}

Yet the deterioration of a detainee's mental state may be the least of his concerns. Some defendants with mental health conditions have it far worse. Unable to follow the strict rules and regulations of a jail environment, they are punished and placed in solitary confinement at much higher rates than the general population. ${ }^{81}$ In Pennsylvania and South Carolina, for example, an inmate ${ }^{82}$ with a mental health condition is twice as likely to be placed in solitary confinement as an inmate without one ${ }^{83}$ - and those inmates are particularly susceptible to the wellknown psychological harms of solitary confinement. Even for prisoners with no history of mental illness, the conditions of extended solitary confinement "may press the outer bounds of what most humans can psychologically tolerate." 84

For prisoners with mental illness, placing them in isolation is akin to "putting an asthmatic in a place with little air to breathe." 85 As one doctor testified, isolating prisoners in small cells for twenty-three hours a day intensifies any preexisting mental illness:

Prisoners who are prone to depression and have had past depressive episodes will become very depressed in isolated confinement. People who are prone to suicide ideation and attempts will become more suicidal in that setting. People who are prone to disorders of mood, either bipolar . . . or depressive[,] will become that and will have a breakdown in that direction. And people who are psychotic in any way ... those people will tend to start losing touch with reality because of the lack of feedback and the lack of social interaction and will have another breakdown, whichever breakdown they're prone to. ${ }^{86}$

80. Human Rights WATCh, Ill-EQuipPed: U.S. PRISONS AND OFFENDERS with MENTAL ILlneSs 54 (2003) (quoting Cheryl D. Wills, The Impact of Conditions of Confinement on the Mental Health of Female Inmates Remanded to Alabama Department of Corrections, prepared for Laube v. Haley, No. 02-T-957-N (M.D. Ala. 2002)) [hereinafter HRW, ILL-EQUIPPED].

81. See, e.g., SUBRAMANIAN ET AL., supra note 74, at 12 (noting that defendants with mental illness are more likely to be placed in solitary confinement "either as punishment for breaking rules or for their own protection since they are also more likely to be victimized").

82. I use the term "inmate" to refer to residents of both jails and prisons in the discussions on solitary confinement, abuse, and neglect, as the studies to which I am referring make no distinction between the two.

83. Human Rights Watch, Callous and Cruel: Use of Force against Inmates with Mental Disabilities IN U.S. Jails AND PRISONS (2015), https://www.hrw.org/report/2015/05/12/ callous-and-cruel/use-force-against-inmates-mental-disabilities-us-jails-and [https://perma.cc/B36K-XM2W] [hereinafter HRW, CALLOUS AND CRUEL].

84. Madrid v. Gomez, 889 F. Supp. 1146, 1267 (N.D. Cal. 1995) (finding solitary confinement constitutes cruel and unusual punishment for prisoners living with mental illness); see also Reginald Dwayne Betts, Only Once I Thought About Suicide, 125 YALE L.J. F. 222, 228 (2016) (describing his time in solitary confinement: "Each day, I lost a little bit of what made me want to be free. . . One afternoon, in a fit of panic, I slammed my right fist against the wall. I fractured my pinky. I thought about suicide. I almost disappeared.”).

85. Madrid, 889 F. Supp. at 1265.

86. HRW, ILL-EQUIPPED, supra note 80, at 152 (quoting testimony of Dr. Terry Kupers in Jones 'El v. Berge, No. 00-C-0421-C (W.D. Wis. 2001)). 
Predictably, tragedy occurs when individuals with mental illness are placed in isolation. Suicide rates are higher among inmates in segregation units than those in the general population. ${ }^{87}$ One inmate mutilated his own genitals while in solitary confinement. ${ }^{88}$ Another prisoner in isolation refused food and medication, ingested feces, and smeared feces on himself. ${ }^{89}$ Eleven days after his transfer to the segregation cell, he was found lying naked on the floor covered in vomit, urine, and feces. He was hypothermic by the time he reached the hospital and died after going into cardiac arrest. ${ }^{90}$

\section{Abuse and Neglect}

Even if an inmate with mental illness avoids solitary confinement, he will still be targeted by guards and other inmates. ${ }^{91}$ Individuals with mental health disorders are twice as likely to be injured in a fight with another inmate. ${ }^{92}$ Eight percent of male prisoners with a mental illness reported being sexually assaulted, as compared to three percent of male prisoners without a mental health disorder. ${ }^{93}$ Twenty-three percent of female inmates with a mental health condition have reported a sexual assault. ${ }^{94}$

Individuals with mental health conditions are not just victims of other inmates, but also of the guards charged with their protection. In South Carolina, prison guards used force against these inmates at a rate 2.5 times higher than other inmates. ${ }^{95}$ In Colorado, prisoners living with mental illness accounted for three percent of the prison population but thirty-six percent of use-of-force incidents. ${ }^{96}$ In New York, over the course of eleven months, corrections officers at Rikers Island beat 129 inmates so badly that they suffered "serious injuries" beyond the capacity of the jail clinic to treat, such as ruptured eardrums, broken jaws, and

87. See Raymond F. Patterson \& Kerry Hughes, Review of Completed Suicides in the California Department of Corrections and Rehabilitation, 1999 to 2004, 59 PSYCHIATRIC SERVS. 676, 678 (2008) ("We found that the conditions of deprivation in locked units and higher-security housing were a common stressor shared by many of the prisoners who committed suicide.").

88. Jason M. Breslow, What Does Solitary Confinement Do to Your Mind?, FrontLine (Apr. 22, 2014), https://www.pbs.org/wgbh/frontline/article/what-does-solitary-confinement-do-to-your-mind/ [https://perma.cc/6PFQ-7PGK].

89. HRW, CALlOUS AND CRUEL, supra note 83.

90. Id.

91. See id. ("Experts we consulted for this report said that force is used disproportionately against prisoners with mental illness.”).

92. Seena Fazel et al., Mental Health of Prisoners: Prevalence, Adverse Outcomes, and Interventions, 3 LANCET PSYCHIATRY 871, 875 (2016).

93. Id.

94. Id.; Annette S. Crisanti \& B. Christopher Frueh, Risk of Trauma Exposure Among Persons with Mental Illness in Jails and Prisons: What Do We Really Know? 24 CURRENT OPINION PSYCHIATRY 431, 433 (2011). These numbers are likely significantly higher, as sexual assault is an underreported crime both inside and outside the correctional system. Only twenty-two percent of male and thirty-four percent of female inmates report their assaults. See Shannon K. Fowler et al., Would They Officially Report an In-Prison Sexual Assault? An Examination of Inmate Perceptions, 90 PRISON J. 220, 221 (2010).

95. HRW, CALlOUS AND CRUEL, supra note 83.

96. Id. 
head trauma. ${ }^{97}$ Most of the inmates at Rikers are pretrial detainees, ${ }^{98}$ and seventyseven percent of the beaten inmates had a diagnosed mental illness. ${ }^{99}$ Elsewhere, one inmate diagnosed with mental illness died after guards sprayed him with scalding water. ${ }^{100}$ Another tried to commit suicide; rather than taking the prisoner for medical care, guards handcuffed him and punched him with such force "that he suffered a perforated bowel and needed emergency surgery."101 A third died from asphyxiation after officers restrained him, then allegedly kicked, choked, and stomped on him. ${ }^{102}$

Detainees with mental illnesses who are not actively abused in prison may suffer from neglect, which can lead to equally tragic outcomes. To take just a few examples: Jamycheal Mitchell, the young man from Virginia described at the beginning of this Article, died after languishing in his jail cell for months. Other inmates alleged that prison guards had denied Mitchell food, cut off water to his cell, and confiscated his bed sheets, mattress, and clothing after Mitchell smeared feces on the wall of his cell. ${ }^{103}$ By the time of his death, he had lost forty pounds. ${ }^{104}$ In Florida, a man with schizophrenia gouged out his eyes while awaiting hospital admission and treatment. ${ }^{105}$ On Rikers Island, an inmate in a mental health unit died after being found in an overheated jail cell; an officer should have been making rounds to check on the inmates but remained in her chair for most of her shift. ${ }^{106}$

Since 2010, at least 404 people with a mental health condition have died in America's jails. ${ }^{107}$ The total number is likely much higher, but many states and the federal government do not track the mental health status of inmates who die

97. Michael Winerip \& Michael Schwirtz, Rikers: Where Mental Illness Meets Brutality in Jail, N.Y. TIMES (July 14, 2014), https://www.nytimes.com/2014/07/14/nyregion/rikers-study-finds-prisonersiniured-by-employees.html [https://nyti.ms/W2jVRi].

98. Michael Schwirtz, What Is Rikers Island?, N.Y. Times (Apr. 5, 2017), https://www.nytimes.com/ 2017/04/05/nyregion/rikers-island-prison-new-york.html [https://nyti.ms/2oJAH6O] ("Most of the inmates-about 85 percent-have not yet been convicted of a crime; they are pretrial detainees, either held on bail or remanded to custody.").

99. Winerip \& Schwirtz, supra note 97.

100. Eyal Press, Madness: In Florida Prisons, Mentally Ill Inmates Have Been Tortured, Driven to Suicide, and Killed by Guards, NEw YORKER (May 2, 2016), https://www.newyorker.com/magazine/ 2016/05/02/the-torturing-of-mentally-ill-prisoners [https://perma.cc/6287-YSCN].

101. Winerip \& Schwirtz, supra note 97.

102. HRW, CALLOUS AND CRUEL, supra note 83.

103. Complaint at 5-7, Adams v. Naphcare, Inc., 246 F. Supp. 3d 1128 (E.D. Va. 2017) (No. 2:16cv-229), aff'd in part, rev'd in part sub nom. Adams v. Ferguson, 884 F.3d 219 (4th Cir. 2018).

104. Id. at 6 .

105. Hal Wortzel et al., Crisis in the Treatment of Incompetence to Proceed to Trial: Harbinger of a Systemic Illness, 35 J. AM. ACAD. \& PSYCHIATRY L. 357, 359 (2007).

106. Michael Schwirtz, Correction Dept. Investigating Death of Inmate at Riskers Island, N.Y. TiMES (Mar. 19, 2014), https://www.nytimes.com/2014/03/20/nyregion/correction-dept-investigatingdeath-of-inmate-at-rikers.html [https://nyti.ms/115cl2j].

107. Gary A. Harki, Horrific Deaths, Brutal Treatment: Mental Illness in America's Jails, VIRGINIANPILOT (Aug. 23, 2018), https://pilotonline.com/news/local/projects/jail-crisis/article_5ba8a112-974e-11e8ba17-b734814f14db.html [https://perma.cc/4A7Y-2TE7]. 
while in custody. ${ }^{108}$

\section{The Stigma Against Individuals with Mental Health Conditions}

These negative outcomes-longer periods detained and harmful effects of detention-result from the large numbers of defendants found incompetent and ordered into inpatient treatment. Why do so many incompetence findings end with an order for transfer to the state mental health facility? In part, this is due to a shortage of community options; only a handful of states operate outpatient treatment centers, and even the most robust outpatient programs only accept a handful of defendants. ${ }^{109}$

But even if every state immediately opened outpatient facilities that could serve large numbers of patients, the statutes governing competence restoration would likely continue to default to inpatient care. Some jurisdictions require this outcome. ${ }^{110}$ Other statutes give judges broad discretion on where to place defendants, inviting them to consider questions such as whether the defendant is dangerous. ${ }^{111}$ When paired with the entrenched stigma that surrounds individuals with mental health conditions, these statutes, too, lead to inpatient commitment. In the next section, I dive into the language of those statutes and show how they lead to an inpatient default. Here, I describe the stigma that likely influences decisionmaking in this arena.

Michael Perlin described the misunderstandings of and prejudice toward individuals with mental health conditions as "sanism," and identified some of the many sanist myths that infect the criminal justice system. ${ }^{112}$ One of the most staunchly held beliefs is that individuals living with mental illness are more dangerous than non-mentally ill individuals. ${ }^{113}$ A second sanist myth is that defendants found incompetent to stand trial are best treated in a hospital setting. ${ }^{114}$ However, neither of these myths accurately reflect the current understanding of mental health conditions and individuals living with them. Instead, these assumptions are historical remnants from a time when mental illness was poorly understood and greatly feared. ${ }^{115}$ The following sections attempt to disable the two sanist myths that undergird much of the decisionmaking in competence

108. Id

109. See Gowensmith et al., supra note 18, at 299.

110. See infra Section III.B.1.

111. See infra Section III.B.2.

112. See generally Perlin, supra note 24 (identifying "sanism" as an irrational prejudice like sexism or racism and explaining its impact on the law).

113. Id. at 394.

114. See Michael L. Perlin, Pretexts and Mental Disability Law: The Case of Competency, 47 U. MiAmi L. REV. 625, 680-81 (1993).

115. See Perlin, supra note 24, at 388-89 ("The roots of sanism are deep. From the beginning of recorded history, mental illness has been inextricably linked to sin, evil, God's punishment, crime, and demons. Evil spirits were commonly relied upon to explain abnormal behavior. The 'face of madness ... haunts our imagination.' People with mental illness were considered beasts; a person who lost his capacity to reason was seen as having lost his claim 'to be treated as a human being."' (citations omitted)). 
restoration: the assumed dangerousness of individuals with mental health conditions and the assumed need for treatment in a mental health facility to successfully restore competence.

\section{A. DANGEROUSNESS}

In a 2013 national survey, "[a]lmost half of respondents believed that people with serious mental illness [were] more dangerous than the general population." 116 News coverage of mass shootings and other violent acts enhances this belief. In one study, individuals who read a news story about a mass shooting committed by an individual with mental illness were more likely to believe that all people with mental health conditions were dangerous. ${ }^{117}$

The policy conversations held in the wake of mass shootings further this impression. Conversations about legislation to prevent mass shootings inevitably involve restrictions on the ability of people with mental health conditions to obtain firearms, regardless of whether the shooter actually suffered from a diagnosed serious mental illness. At the time of this writing, the shooting that killed seventeen students at Marjory Stoneman Douglas High School in Florida is dominating the news. Almost immediately after the shooting, advocates and legislators called for restrictions on the sale of firearms to people with mental health conditions as a way to prevent such shootings in the future. However, there is little indication that such restrictions would have prevented the shooter himself, who had been diagnosed with depression and autism—not a psychotic disorder-from buying a firearm. ${ }^{118}$

In addition, perpetrators of mass shootings are assumed to be "mentally ill" merely because they committed such an atrocious crime. But if the definition of "mental illness" is limited to those who suffer from psychotic symptoms—which would exclude individuals who display characteristics of personality disorders, such as resentment or entitlement—only twenty-two percent of mass murders would qualify as carried out by an individual with mental illness. ${ }^{119}$

116. Colleen L. Barry et al., After Newtown-Public Opinion on Gun Policy and Mental Illness, 368 NEW ENG. J. MED. 1077, 1081 (2013).

117. See Jeffrey W. Swanson et al., Mental Illness and Reduction of Gun Violence and Suicide: Bringing Epidemiologic Research to Policy, 25 AnNAls of EPIDEMIOLOGY 366, 367 (2015).

118. See Susan Ferrechio, Paul Ryan: Congress Should Focus on Mental Health and Background Checks, Not Gun Ban, WASH. EXAMINER (Feb. 27, 2018), http://www.washingtonexaminer.com/paulryan-congress-should-focus-on-mental-health-and-background-checks-not-gun-ban/article/2650142 [https://perma.cc/K97D-JL4U]; Eric Levenson, These Are the Gun Bills Florida Lawmakers Are Debating After the Parkland Massacre, CNN (Feb. 28, 2018), https://www.cnn.com/2018/02/27/ politics/fl-bills-guns-parkland-shooting/index.html [https://perma.cc/NB9J-K8WW]; Phil McCausland, Florida Mental Health Agency Examined Cruz in 2016, Didn't Hospitalize Him, NBC News (Feb. 18, 2018), https://www.nbcnews.com/news/us-news/social-media-post-led-florida-agency-investigate-nikolascruz-2016-n849221 [https://perma.cc/F68K-4K3U].

119. Michael H. Stone, Mass Murder, Mental Illness, and Men, 2 Violence \& Gender 51, 76 (2015); see also id. (“[M] ass killers are rarely insane and don't typically have delusions or the psychotic fantasies of the paranoid schizophrenic; instead, they usually have personality disorders-with narcissistic and paranoid traits such as entitlement, self-righteousness, and resentment." (citing generally Michael Kelleher, Flash Point: The American Mass Murderer (1997))). 
Although links between relatively rare mass murders and mental illness are weaker than the public tends to believe, links between mental illness and more common violent acts are even more attenuated. Recent studies on the connection between mental illness and violence have debunked the myth that people with a mental health condition are inherently more dangerous than other people. One study of more than one thousand discharged psychiatric patients over the course of a year found that patients with mental illness who did not abuse alcohol or drugs were no more likely to be violent than their neighbors. ${ }^{120}$ Another study acknowledged that individuals with mental illness were moderately more likely to engage in violence than others; however, the study also found that the relationship was significantly attenuated when serious life stressors were consideredwhich indicates that the stressor, rather than the mental illness, may be a more significant predictor of violence. ${ }^{121}$ As one psychiatrist explained:

It's time that ... we begin to knock down stereotypes and start breaking down the stigma associated with mental disorders. The first stereotype to go downpermanently, we hope-is that people who suffer from depression, anxiety, schizophrenia, an eating disorder, or any other type of mental disorder, are somehow more violent than others. This simply isn't true, unless they are involved in substance abuse. Use and abuse of substances such as drugs or alcohol is often correlated with an increase in violence anyway ....

Violence is most often a criminal activity which has little correlation with a person's mental health. Most people who suffer from a mental disorder are not violent - there is no need to fear them. ${ }^{122}$

Of the small number of individuals with a mental health condition who did commit violent acts, those with schizophrenia were much less violent than those who suffered from major depressive disorder, ${ }^{123}$ which flies in the face of assumptions that individuals living with psychotic symptoms are the most likely to act violently. ${ }^{124}$ In fact, delusions were not associated with violent behavior, even if the individual believed someone was out to harm him or was controlling his thoughts. ${ }^{125}$ Individuals rarely harm others because a voice in their head tells

120. John Monahan et al., Rethinking Risk Assessment: The MacArthur Study of Mental DisORDER AND VIOLENCE 33 (2001). The study also noted that the discharged patients were more likely to abuse alcohol and drugs than their neighbors. $I d$.

121. See Eric Silver \& Brent Teasdale, Mental Disorder and Violence: An Examination of Stressful Life Events and Impaired Social Support, 52 Soc. PROBS. 62, 72 (2005).

122. John M. Grohol, Dispelling the Myth of Violence and Mental Illness, PsYCHCENTRAL (June 1998), http:// psychcentral.com/archives/violence.htm [https://perma.cc/F7JT-DR6N].

123. See Heather Stuart, Violence and Mental Illness: An Overview, 2 WORLD PSYCHIATRY 121, 122-23 (2003).

124. Paul S. Appelbaum et al., Violence and Delusions: Data from the MacArthur Violence Risk Assessment Study, 157 AM. J. PsychiATRY 566, 571 (2000) ("Contrary to popular wisdom and to the results of several other studies, the data from this study suggest that the presence of delusions does not predict higher rates of violence among recently discharged psychiatric patients.").

125. Id. 
them to. Instead, the factors that best predict violence in persons living with mental illness are the same that are thought to predict violence in all humans: being young, male, poor, and addicted to drugs or alcohol. ${ }^{126}$

If judges hold the same misconceptions as the general public, then they may be reluctant to send back into the community individuals who, in their view, are at high risk of committing violent crimes. ${ }^{127}$ In some ways, judges may be even more susceptible to the dangerousness myth, as they will likely face public backlash if the defendant does turn violent. Although few studies have looked at the impact of risk aversion in pretrial release decisions, judges who have released defendants only to have them commit crimes have faced significant public criticism. ${ }^{128}$ As one D.C. Superior Court judge said, "It's one of my biggest fears . . . . No judge wants to release someone and have that person commit a violent crime while on release."129

\section{B. NECESSITY OF HOSPITALIZATION}

In the past, institutionalization was the only option for individuals suffering from severe mental illness. Before the widespread adoption of medications to treat mental health conditions, individuals living with schizophrenia or other psychotic disorders would be locked away in a distant institution and subjected to wretched conditions. ${ }^{130}$ Those who were arrested and found incompetent had it even worse: they were sent to specialized wards for the criminally insane, which

126. Stuart, supra note 123 , at 123.

127. The presumption that judges hold these same biases is up for debate. Some studies have shown that individuals with legal training hold implicit or explicit biases, but those biases did not affect their decisionmaking; other studies showed the opposite. Erik J. Girvan, Wise Restraints? : Learning Legal Rules, Not Standards, Reduces the Effects of Stereotypes in Legal Decision-Making, 22 PsYCHOL. PuB. POL'Y \& L. 31, 31 (2016).

128. See, e.g., Bill Gallo Jr., Murder Suspect Had Been Arrested Earlier on Gun Charge, Then Released, NJ.COM (Apr. 13, 2017), http://www.nj.com/cumberland/index.ssf/2017/04/murder_suspect_had_been_ arrested_on_earlier_gun_ch.html [https://perma.cc/6MV7-K34N] ("The president of the local police union believes Black's release is an example of the failings of the new bail reform law ...."); Peter Hermann \& Keith L. Alexander, D.C. Murder Suspect Freed Until Trial Arrested Again, WASH. Post (Jan. 30, 2013), https://www.washingtonpost.com/local/dc-murder-suspect-freed-until-trial-arrested-again/2013/01/ 30/ca93b574-6b0a-11e2-ada3-d86a4806d5ee_story.html?utm_term=.986004b49fc4 [https://perma. cc/W7ZV-8YN9] (quoting the friend of a murder victim allegedly killed by a man on release awaiting trial for murder: "Why ... did the law allow this? Does a life not mean anything?"); Eric Westervelt, Did a Bail Reform Algorithm Contribute to This San Francisco Man's Murder?, NPR (Aug. 18, 2017), https://www. npr.org/2017/08/18/543976003/did-a-bail-reform-algorithm-contribute-to-this-san-francisco-man-s-murder [https://perma.cc/GBZ4-KRVR] (quoting the partner of the murder victim about the accused: "I mean, he's violated two probations. He was a convicted felon. And he had a gun charge just five days before the murder of Ed French! It's absolutely crazy. I think the judge has to be held accountable.").

129. Keith L. Alexander, 11 Defendants on GPS Monitoring Charged with Violent Crimes in Past Year in D.C., WASH. Post (Feb. 9, 2013), https://www.washingtonpost.com/local/11-defendants-ongps-monitoring-charged-with-violent-crimes-in-past-year-in-dc/2013/02/09/9237be1e-6c8b-11e2-ada05ca5fa7ebe79_story.html?utm_term=.89b17a025a99 [https://perma.cc/4EKB-7YNN].

130. E.g., Douglas Mossman, Unbuckling the "Chemical Straitjacket": The Legal Significance of Recent Advances in the Pharmacological Treatment of Psychosis, 39 SAN DIEGo L. REV. 1033, 1063-64 (2002). 
were devoted to warehousing and offered little in the way of treatment. ${ }^{131}$ As one court noted:

Petitioner testified without contradiction that he had been assaulted by mentally deranged persons in shackles. He described noisome, unnatural and violent acts by inmates in this Hall....

... [T]he facts which petitioner asserts depict a place of confinement for the hopeless and the violent, not a place of remedial restriction. ${ }^{132}$

In recent decades, a medical breakthrough sparked a move away from institutions and toward community treatment. Antipsychotic medications, the first truly effective treatment for psychotic symptoms, became available in the 1950s. ${ }^{133}$ The drugs "made the wholesale removal of patients from hospitals imaginable and then possible." 134 Since the advent of medication-based treatment, the population of state mental institutions has decreased by ninety percent. ${ }^{135}$ A 1961 report of the Joint Commission on Mental Illness and Health called the medications "the greatest blow for patient freedom, in terms of nonrestraint, since Pinel struck off the chains of the lunatics in the Paris asylum 168 years ago."136

Although this transition to care in the community was not without its significant failures, as described in more detail below, it did mark a shift away from confinement as the primary mode of psychiatric care. Yet the move away from inpatient care did not cross over into the criminal realm. Defendants found incompetent continued to be sent to inpatient facilities in large numbers, with little consideration of whether the placement was therapeutically desirable. ${ }^{137}$

A few possible explanations exist for this discrepancy of community-treatment default for civil patients and inpatient default for criminal ones. Judges may assume that an individual who is accused of a crime is more in need of inpatient care than an individual who has a mental health condition but has not been arrested. But there is little data to support that conclusion and much anecdotal evidence to contradict it.

First, the mere fact of arrest bears little relationship to the ability of the defendant to be restored in the community. The criminalization of minor offenses means that if you "drive a car, walk, or stand on a sidewalk or public road, you likely

131. Caleb Foote, A Comment on Pre-Trial Commitment of Criminal Defendants, 108 U. PA. L. REV. 832,843 (1960).

132. Miller v. Overholser, 206 F.2d 415, 418-19 (D.C. Cir. 1953).

133. Mossman, supra note 130, at 1062-63.

134. Id. at 1064 (quoting ANn BRADEN Johnson, Out of Bedlam: The Truth About Deinstitutionalization 45-46 (1990)).

135. Id. at 1065 .

136. Id. (quoting Joint Comm'N on Mental Illness and Health, Action for Mental Health 39 (1961)). This is not to say that the history of deinstitutionalization has been a success. But, as noted below, the failures of deinstitutionalization are likely due to a lack of funding for community programs. See infra notes 148-53 and accompanying text. The lesson to be taken from deinstitutionalization policy is that inpatient treatment is not always the better solution.

137. See supra Part I. 
subject yourself to the legal possibility of arrest." 138 This is particularly true for a person living with mental illness, who may be unable to comport himself with the societal expectations for behavior in public and may find himself facing a disorderly conduct charge, one of the most common charges filed against defendants with a mental health condition. ${ }^{139}$ The simple fact of an arrest may mean little more than that the defendant was in the wrong place at the wrong time, and arrest alone should have no bearing on whether he could be successfully restored through outpatient treatment.

Second, the success some states have had with preventive outpatient commitment statutes indicates that even individuals with arrest records can be successfully treated in the community. These laws allow courts to require an individual to submit to treatment in an outpatient setting, even if that individual falls short of the criteria for involuntary hospitalization. ${ }^{140}$ The individuals subject to these laws may have had past run-ins with law enforcement, similar to defendants found incompetent to stand trial. ${ }^{141}$ Under the New York statute, for example, individuals must have a history of non-compliance with past treatment that has resulted in either hospitalization or acts of violence. ${ }^{142}$ One study showed that these patients improved within the first six months of outpatient treatment, notching substantial increases in social functioning and ability to perform tasks, and decreases in incidence of harmful behaviors. ${ }^{143}$ Court-ordered treatment in the community worked for these hard cases and could have similar positive results for persons found incompetent.

Another assumption justifying the inpatient default for criminal defendants may be that individuals found incompetent are necessarily the sickest of the sick, and the only appropriate venue for restoring their competence is an inpatient facility. However, this assumption, too, falls apart under scrutiny.

The competence standard does not measure the severity of mental illness or the necessity of inpatient treatment. It looks to whether a defendant is able "to consult with his lawyer with a reasonable degree of rational understanding — and whether he has a rational as well as factual understanding of the proceedings against him." 144 Compare that to the American Psychiatric Association's standard for hospitalization of individuals living with psychotic symptoms, which provides that a person requires inpatient treatment only when he is "so severely

138. Ian Weinstein, The Adjudication of Minor Offenses in New York City, 31 FordHAM URB. L.J. $1157,1162-63$ (2004).

139. E. Fuller Torrey et Al., Criminalizing the Seriously Mentally Ill: The Abuse of Jails as Mental Hospitals 46 (1992).

140. See, e.g., Richard C. Boldt, Perspectives on Outpatient Commitment, 49 New ENG. L. REv. 39 , $60 \&$ n. 115 (2014).

141. Id. at 55-56.

142. N.Y. MENTAL HyG. LAW $\S 9.60(c)(4)$ (McKinney 2015).

143. N.Y. State Office of Mental Health, Kendra's Law: Final Report on the Status of Assisted OutPatient TREATMENT 12-17 (2005), https://www.omh.ny.gov/omhweb/kendra_web/ finalreport/aotfinal2005.pdf.

144. See Dusky v. United States, 362 U.S. 402, 402 (1960). 
disorganized or under the influence of delusions or hallucinations that [he is] unable to care for [himself] and need[s] constant supervision or support." ${ }^{145}$

The Venn diagram of these two standards may overlap, but the standards are not coextensive. For example, some defendants found incompetent have been diagnosed with delusional disorder. ${ }^{146}$ The main symptom is a persistent delusion, but the individual's functioning is not otherwise impaired. ${ }^{147}$ If a defendant holds a delusion that the CIA is pursuing her, she may view her arrest and prosecution through the lens of that delusion, thus making her unable to understand the proceedings against her in a rational way. Yet her functioning in general is not impaired, so she could care for herself and does not need constant supervision. She is incompetent, yet does not require hospitalization.

Judges may also believe inpatient care is the best option because of the sordid history of deinstitutionalization. But here, too, the fear is not grounded in reality. The master narrative of deinstitutionalization is one of unmitigated disaster. ${ }^{148}$ Deinstitutionalization reforms, enacted in the 1980s and enabled by the advent of antipsychotic medications, moved individuals living with mental illness out of asylums and into the community. ${ }^{149}$ The promise of community-based treatment and support for these individuals did not become reality, and an enormous increase in homelessness among those with mental illness was laid at the feet of the policy. ${ }^{150}$ Critics of deinstitutionalization have denounced it as "one of the era's most stunning public policy failures." ${ }^{151}$ Thus, it may be that judges, who see many of these homeless individuals in their courtrooms, are concerned about creating a parallel "deinstitutionalization" of the criminal system and adding to the ongoing problem. They also could be motivated by a benevolent urge to ensure treatment for defendants living with mental illness who may have fallen through the deinstitutionalization cracks. ${ }^{152}$

However, the historical record is more complex: some argue that it was cuts to social welfare programs in the 1980 s, not deinstitutionalization itself, that caused skyrocketing rates of homelessness among those living with mental

145. Am. Psychiatric Ass'n, Practice Guideline for the Treatment of Patients with SCHIZOPHRENIA 54 (2d ed. 2010), https://psychiatryonline.org/pb/assets/raw/sitewide/practice_guidelines/ guidelines/schizophrenia.pdf.

146. See, e.g., United States v. Bush, 585 F.3d 806, 809 (4th Cir. 2009).

147. Am. Psychiatric Ass'n, Diagnostic and Statistical Manual of Mental Disorders 9091 (5th ed. 2013).

148. See, e.g., Samuel R. Bagenstos, The Past and Future of Deinstitutionalization Litigation, 34 CARdozo L. ReV. 1, 2-3 (2012).

149. Id.

150. Robert Weisberg, Restorative Justice and the Danger of “Community," 2003 UTAH L. REV. 343,364 .

151. David Mechanic \& David A. Rochefort, Deinstitutionalization: An Appraisal of Reform, 16 AnN. Rev. Soc. 301, 302 (1990).

152. One survey of judges found that a majority $(53.4 \%)$ ordered defendants committed for competency evaluations as a "means of ensuring adequate treatment" for individuals with a mental health condition who appear in court, even though obtaining treatment is not the purpose of those evaluations. Kenneth L. Appelbaum \& William H. Fisher, Judges' Assumptions About the Appropriateness of Civil and Forensic Commitment, 48 PSYCHIATRIC SERVS. 710, 711 (1997). 
illness. ${ }^{153}$ But even assuming the common wisdom about deinstitutionalization is true-that it caused a massive crisis of homelessness and suffering among those living with mental health conditions-concerns about those failures would not justify an inpatient treatment default for defendants found incompetent to stand trial.

The main reason is that defendants moved from inpatient facilities to community treatment must abide by the conditions of their release, unlike patients freed from mental institutions during deinstitutionalization. ${ }^{154}$ Judges would likely require that defendants in outpatient care comply with a treatment regimen; defendants who did not could be returned to jail. This level of supervision was not present during the process of deinstitutionalization. Patients were not required to obtain treatment, and many did not. ${ }^{155}$ Because courts retain significant control over a defendant's treatment success, the prospect of large numbers of defendants falling through the cracks is not as likely as it was with unmonitored patients post-deinstitutionalization.

Thus, an outpatient default for defendants found incompetent to stand trial would be more akin to the assisted outpatient treatment programs described above than to deinstitutionalization. In outpatient treatment programs, defendants are under court orders to comply with treatment and check in with the court on a regular basis. ${ }^{156}$ These programs have seen good rates of success, with most defendants complying with medication regimes and few defendants rearrested. ${ }^{157}$

\section{The Law of Competence}

These sanist myths - that persons living with mental illness are more dangerous than other individuals and that hospitalization is nearly always the best course for defendants found incompetent to stand trial-are not grounded in fact or evidence. But they often form the backdrop against which a judge makes her decision on where to place an incompetent defendant for competence restoration, pushing her in the direction of inpatient treatment. Meanwhile, statutes governing competence restoration do little to counterbalance this instinct, and in many cases reinforce it. Some statutes mandate inpatient treatment. Others preference it. Still others allow for outpatient care but discourage judges from choosing this option.

This Part traces the history of confinement for defendants found incompetent to stand trial and shows how the language of modern statutes continues to

153. Bagenstos, supra note 148 , at 3-4.

154. See Nancy K. Rhoden, The Limits of Liberty: Deinstitutionalization, Homelessness, and Libertarian Theory, 31 EMORY L.J. 375, 387 (1982) (“[T]he 'community' to which many patients are released is a large and hostile metropolis, and the 'treatment' which they receive is often nothing more than a renewable prescription for tranquilizing drugs.").

155. Id. at 390 ("Released patients left to fend for themselves may be unable to take advantage of the services [including medical care] for which they are eligible because such services are not organized in any accessible fashion.").

156. See e. e.g., N.Y. State OfFice of Mental Health, supra note 143, at 10-11.

157. See id. at 11-17. 
manifest sanist impulses by explicitly or implicitly defaulting to inpatient treatment.

\section{A. COMPETENCE IN COMMON LAW AND CONSTITUTIONAL LAW}

The idea that the state could not prosecute an individual who was mentally unfit originated with the English requirement that a defendant enter a plea to the charges against him. Some defendants remained silent, and the courts began to distinguish between those defendants who were "mute of malice" and would thus be tortured until they entered a plea, and those "mute by visitation of God," meaning they were physically incapable of speaking. ${ }^{158}$ At some point in the seventeenth century, English judges recognized that some defendants refused to plead because they were "lunatics," and these defendants were added to the "mute by visitation of God" category. ${ }^{159}$ An individual thought to be a lunatic was put to a trial by jury to determine whether he was "absolutely mad." 160 If the jury found he was, he was confined to prison, presumably with little of what we would consider mental health treatment, until he could plead to the charge. ${ }^{161}$

Thus, the common law competence doctrine evolved out of the recognition that an individual with mental illness often could not provide what was required of him by trial proceedings. The cure for this was not to release the defendant as a hopeless case or as someone who could not be tried, but to hold him in state custody until he could provide the necessary information. As I illustrate below, that default — detaining a defendant until he could participate in the trial process-is a thread that continues to run through modern competence restoration practice.

The prohibition on trying "absolutely mad" defendants carried over from England to the United States, and some jurisdictions-including the federal government — eventually codified those prohibitions in their statutory schemes. ${ }^{162}$ The federal statute became the focus of Dusky v. United States, the first Supreme Court case to address the treatment of defendants with mental illness. ${ }^{163}$

In this two-paragraph opinion, the Court held that the district court used an insufficient standard to find the defendant competent. The lower court had found that the defendant was competent because he was "oriented to time and place and [had] some recollection of events." 164 However, according to the Supreme Court, that finding fell below the federal statutory competence standard, which required that a defendant possess a "sufficient present ability to consult with his lawyer with a reasonable degree of rational understanding" and "a rational as well as

158. See Winick, Reforming Incompetency, supra note 27, at 574.

159. Id.

160. GrP. For the Advancement of Psychiatry, Misuse of Psychiatry in the Criminal COURTS: COMPETENCY TO STAND TRIAL 913 (1974).

161. Id.

162. For example, the U.S. Congress first enacted legislation laying out procedures and standards for mental incompetency in 1949. Act of Sept. 7, 1949, Pub. L. No. 81-285, 63 Stat. 686 (1949) (codified as amended at 18 U.S.C. $\S 4241)$.

163. 362 U.S. 402, 402 (1960).

164. Id. 
factual understanding of the proceedings against him." ${ }^{165}$ Although the exact contours of this language were fuzzy at the time (and remain so today), Dusky introduced the idea that simply showing that the defendant had some sense of where he was and what had happened was no longer enough.

Dusky and the cases that followed expounded on the contours of the competence standard, ${ }^{166}$ but they did not examine the process of restoring competence that followed an incompetence finding. Jackson $v$. Indiana was the first to assess the equal protection and due process implications for a defendant detained while undergoing competence restoration treatment. ${ }^{167}$ In Jackson, the defendant was a "mentally defective deaf mute with a mental level of a pre-school child." ${ }^{168} \mathrm{He}$ was arrested for robbery, but was never tried on the charge because his competence was almost immediately called into question. ${ }^{169}$ One of the two psychiatrists who examined him found his prognosis "rather dim"; the other doubted that he had sufficient intelligence to ever develop the necessary communication skills to be deemed competent to stand trial. ${ }^{170}$ The court found Jackson incompetent and ordered him committed to Indiana's Department of Mental Health until the Department could certify to the court that the defendant was "sane."171 Nearly four years later, Jackson remained in the facility with little hope of ever being restored to competence and with no prospect of release. ${ }^{172}$ For all intents and purposes, he had been given a life sentence without ever being convicted of a crime.

The Supreme Court held that Jackson's indefinite commitment violated his rights to due process and equal protection. ${ }^{173}$ When competence restoration is unlikely or impossible, justification for the detention must shift to some other basis - dangerousness to self or others, for example - to be constitutionally viable. ${ }^{174}$ A defendant found incompetent therefore "cannot be held more than the reasonable period of time necessary to determine whether there is a substantial probability" he will attain competence in the "foreseeable future." ${ }^{.75}$ Due process requires, at minimum, that the "nature and duration of commitment bear some

165. Id.

166. The cases that followed Dusky firmly grounded the competence standard not in federal statutory text but in the Due Process Clause of the Constitution. Pate v. Robinson established this concept, holding that trying a defendant found incompetent violated his constitutional fair trial rights. 383 U.S. 375, 385-86 (1966). A court must therefore hold a hearing whenever evidence raises a "bona fide doubt" as to the defendant's competence. Id. at 385. Drope v. Missouri reiterated the Pate due process standard, explicitly recognizing a trial judge's constitutional obligations to resolve competency issues and to be alert before and during trial to evidence suggesting possible incompetence of a defendant. 420 U.S. 162, 181 (1975).

167. 406 U.S. 715,719 (1972).

168. Id. at 717 .

169. See id.

170. Id. at 719.

171. Id.

172. Id. at 738-39.

173. Id. at 730-31.

174. Id. at 736-38.

175. Id. at 738 . 
reasonable relation" to its purpose of restoring a defendant's competence. ${ }^{176}$

But Jackson gave no guidance as to when, exactly, a pretrial commitment for competence restoration exceeds the bounds of reasonableness. And it did not question the default position that commitment to an inpatient mental health facility was necessary for competence restoration.

\section{B. COMPETENCE RESTORATION STATUTES}

Nearly every state has a statute or court rule governing competence restoration, ${ }^{177}$ and most of these laws default to inpatient treatment. ${ }^{178}$ A substantial minority of jurisdictions mandate that defendants found incompetent to stand trial must be sent to an inpatient facility, with no consideration of the individual circumstances of the case. ${ }^{179}$ These

176. Id.

177. See Alaska Stat. Ann. § 12.47.110(a) (West 2008); Ariz. Rev. Stat. AnN. § 13-4512(A) (2005); Ark. Code Ann. § 5-2-310(a)(1) (West 2017); Cal. Penal Code § 1370(a)(1)(B) (West 2018); Colo. Rev. Stat. Ann. § 16-8.5-111(2) (West 2017); Conn. Gen. Stat. Ann. § 54-56d (West 2016); Del. Code AnN. tit. 11, § 404(a) (West 2012); D.C. Code § 24-531.05 (2012); GA. Code AnN. § 17-7130(c) (West 2017); HAW. Rev. StAT. AnN. § 704-406(1) (West 2016); IdAHO CodE ANN. § 18-212(2) (West 2000); 725 Ill. Comp. StAT. AnN. 5/104-17(a)-(b) (West 2018); Ind. Code AnN. § 35-36-3-1(b) (West 2018); Iowa Code AnN. § 812.6 (West 2014); Kan. STAT. AnN. § 22-3303(1) (West 2018); Ky. Rev. Stat. AnN. § 504.110(1) (West 2005); LA. Code Crim. Proc. AnN. art. 648 (2017); Me. Rev. Stat. AnN. tit. 15, § 101-D(5) (2016); Md. Code AnN., Crim. Proc. § 3-106(b) (West 2018); MASS. Gen. Laws AnN. ch. 123, § 16(a) (West 2015); Мich. Comp. Laws ANN. § 330.2032(3) (West 2018); Mo. Ann. Stat. § 552.020(9) (West 2011); Mont. Code Ann. § 46-14-221(2) (West 2007); Neb. Rev. Stat. AnN. § 29-1823(1) (West 2017); NeV. Rev. Stat. AnN. § 178.425(1) (West 2017); N.H. ReV. StAT. AnN. § 135:17-a (2010); N.J. StAT. AnN. § 2C:4-6(b) (West 1999); N.M. STAT. AnN. § 31-9-1.2 (1999); N.Y. CRIM. Proc. LAW § 730.40(1) (McKinney 2013); N.C. GEN. StAT. ANN. § 15A-1002(a)(2) (West 2017); N.D. Cent. Code AnN. § 12.1-04-08 (West 2013); Ohio Rev. Code AnN. § 2945.38(B) (West 2016); OKLa. Stat. AnN. tit. 22, § 1175.7 (West 2015); Or. Rev. Stat. AnN. § 161.370(2) (West 2018); 50 PA. Stat. AND Cons. Stat. AnN $\$ 7403$ (West 1996); R.I. Gen. LAws AnN. § 40.1-5.3-3(i) (West 2012); S.C. Code ANN. § 44-23-430 (2011); S.D. Codified LAWs § 23A-10A-4 (1999); TenN. Code Ann. § 33-7-301 (West 2015); Tex. Code Crim. Proc. AnN. art. 46B.072 (West 2017); Utah Code AnN. § 77-15-6 (West 2018); VA. Code AnN. § 19.2-169.2 (West 2017); Wash. Rev. Code AnN. \$10.77.086 (West 2015); W. VA. Code AnN. § 27-6A-3 (West 2007); Wis. STAT. AnN. § 971.14(5) (West 2018); Wyo. Stat. AnN. § 7-11-303(g) (West 2010); Ala. R. Crim. P. 11.6(c); Fla. R. CRim. P. 3.212(c); MinN. R. CRIM. P. 20.01(6); MisS. R. CRIM. P. 12.5(d). In Vermont, criminal courts have the ability to commit a defendant who qualifies as "a person in need of treatment," meaning an individual who poses a danger to himself or others, but that power is not directly connected to a finding of incompetence as it is in other states. See VT. STAT. ANN. tit. 13, § 4822(a) (West 2014).

The federal government also has a statute governing treatment of incompetent defendants, 18 U.S.C. $\S 4241$ (2012), although the number of individuals impacted by the federal law is vastly less than those governed by the state statutes. See, e.g., Rochin v. California, 342 U.S. 165, 168 (1952) ("In our federal system the administration of criminal justice is predominantly committed to the care of the States. . . Broadly speaking, crimes in the United States are what the laws of the individual States make them .... "); Robert P. Mosteller, Failures of the American Adversarial System to Protect the Innocent and Conceptual Advantages in the Inquisitorial Design for Investigative Fairness, 36 N.C. J. INT'L L. \& COM. REG. 319, 326-27 (2011) (stating that "although federal criminal law is expanding, criminal justice remains the responsibility of states and localities predominately" and that " $87.5 \%$ of inmates are confined in state prisons").

178. See infra Sections III.B.1-2.

179. See infra Section III.B.1. 
statutes ${ }^{180}$ are the most problematic of the lot because they mandate commitment regardless of individual circumstances.

But problems abound even in those states that allow judges to use their discretion to determine the appropriate placement for a defendant found incompetent. ${ }^{181}$ The standards for determining whether the defendant should be in inpatient treatment are often uncertain and thus ripe for the importation of sanist assumptions about individuals living with mental illness. ${ }^{182}$ Moreover, the incompetence commitment standards are often not linked to the pretrial release criteria in the statutory code, and defendants with mental health conditions thus face a release inquiry that is different - and often harsher - than that faced by their nonmentally ill counterparts. ${ }^{183}$

Although no two competence restoration statutes are identical, many exhibit some problematic commonalities, which I describe below.

\section{Required Inpatient Statutes}

Nine jurisdictions (the federal government and eight states) require courts to hospitalize defendants found incompetent. ${ }^{184}$ Three additional states mandate

180. I am using the term statute for simplicity's sake, but provisions in some states are set out in the state's court rules rather than the statutory code. See, e.g., AlA. R. CRIM. P. 11.6(c); FlA. R. CRIM. P. 3.212(c); MINN. R. CRIM. P. 20.01(6); MISS. R. CRIM. P. 12.5(d).

181. See infra Section III.B.2.

182. See infra Section III.B.2.

183. See infra Section III.B.2.b.

184. 18 U.S.C. $\$ 4241$ (d) ("If, after the hearing, the court finds by a preponderance of the evidence that the defendant is presently suffering from a mental disease or defect rendering him mentally incompetent to the extent that he is unable to understand the nature and consequences of the proceedings against him or to assist properly in his defense, the court shall commit the defendant to the custody of the Attorney General. The Attorney General shall hospitalize the defendant for treatment in a suitable facility . . . ."); IDAHO CODE ANN. § 18-212(2) ("[T]he court shall commit him to the custody of the director of the department of health and welfare, for a period not exceeding ninety (90) days, for care and treatment at an appropriate facility of the department of health and welfare or if the defendant is found to be dangerously mentally ill as defined in section 66-1305, Idaho Code, to the department of correction for a period not exceeding ninety (90) days.”); KAN. STAT. ANN. § 22-3303(1) (“[T]he court shall order the defendant to remain in an appropriate state, county, private institution or facility until the defendant attains competency to stand trial ....”); KY. REV. STAT. ANN. § 504.110(1) ("If the court finds the defendant incompetent to stand trial but there is a substantial probability he will attain competency in the foreseeable future, it shall commit the defendant to a treatment facility or a forensic psychiatric facility ...."); Mo. ANN. STAT. §552.020(9) ("If the court determines that the accused lacks mental fitness to proceed, the criminal proceedings shall be suspended and the court shall commit him to the director of the department of mental health."); MonT. CODE ANN. § 46-14-221(2)(a) ("If the court determines that the defendant lacks fitness to proceed, the proceeding against the defendant must be suspended, . . . and the court shall commit the defendant to the custody of the director of the department of public health and human services to be placed in an appropriate mental health facility . . . or residential facility ... of the department of public health and human services for so long as the unfitness endures or until disposition of the defendant is made pursuant to this section, whichever occurs first."); Neb. Rev. StAT. AnN. § 29-1823(1) ("Should the judge determine after a hearing that the accused is mentally incompetent to stand trial and that there is a substantial probability that the accused will become competent within the foreseeable future, the district judge shall order the accused to be committed to a state hospital for the mentally ill or some other appropriate state-owned or state-operated facility for appropriate treatment until such time as the disability may be removed."); S.C. CODE ANN. 
commitment when the defendant is accused of a felony. ${ }^{185}$

Nebraska is typical of a mandatory-commitment statute: if a judge determines a defendant is incompetent to stand trial, she "shall order the accused to be committed to a state hospital for the mentally ill or some other appropriate stateowned or state-operated facility." 186 Under this statute, a judge in Nebraska has no ability to release the defendant and place him in outpatient care, even if the defendant is not dangerous, poses no flight risk, and would benefit from treatment in the community.

The federal statute is similar, stating that the court "shall commit the defendant to the custody of the Attorney General" to "hospitalize the defendant for treatment in a suitable facility." 187 District courts have no option but to commit defendants, regardless of their potential for successful treatment in the community. One court held that a defendant who was not dangerous and stood little chance of having his competence restored was required to be committed to a mental health facility under this statute. ${ }^{188}$ Another court acknowledged that outpatient treatment was "best for all concerned," and even stated that inpatient treatment risked "permanent harm" to the defendant, but ordered him into the custody of the Attorney General regardless. ${ }^{189}$

Jurisdictions with mandatory-commitment statutes are declining in number, and several states (along with the District of Columbia) have changed their

§ 44-23-430 ("If . . . the court finds that ... the person is unfit to stand trial but likely to become fit in the foreseeable future, the court shall order him hospitalized up to an additional sixty days."); S.D. CODIFIED LAws $\S 23 \mathrm{~A}-10 \mathrm{~A}-4$ ("[T] having residential capability.").

185. Alaska StAT. ANN. $\$ 12.47 .110$ (a) (mandating that courts "shall commit" defendants accused of felonies to the state department of mental health, but "may commit" defendants charged with other crimes); GA. CODE ANN. § 17-7-130(c)(3) (instructing that if "there is a substantial possibility" a defendant will attain competence, the state mental health department "shall retain custody over the accused," but if the accused is charged with a misdemeanor or nonviolent offense, "the court ... may, in its discretion, allow continued treatment to be done on an outpatient basis"); LA. CODE CRIM. PROC. ANN. art. 648(A)(1) ("[I]f the person is not charged with a felony . . the court may order outpatient care and treatment ...."). I count these states in this tally because partially inpatient-required statutes suffer from some of the same deficits as the fully mandatory inpatient jurisdictions above: a defendant charged with a felony crime may not be dangerous, pose a flight risk, or require inpatient care to ensure compliance with a medication regime. Nevertheless, they are placed in the most restrictive environment by default.

186. Neb. Rev. Stat. AnN. § 29-1823(1) (emphasis added).

187. 18 U.S.C. $\$ 4241$ (d) (emphasis added).

188. See United States v. Shawar, 865 F.2d 856, 860 (7th Cir. 1989) (“The plain meaning of this phrase is, and we hold it to be, that once a defendant is found incompetent to stand trial, a district judge has no discretion in whether or not to commit him."); see also, e.g., United States v. Ferro, 321 F.3d 756, 761 (8th Cir. 2003) ("[A]fter determining that a defendant is incompetent to stand trial, a district court is required to commit the defendant to the custody of the Attorney General . ..."); United States v. Filippi, 211 F.3d 649, 652 (1st Cir. 2000) ("[T] he statute is categorical in determining who shall be incarcerated ... .”); United States v. Donofrio, 896 F.2d 1301, 1302 (11th Cir. 1990) (“"T]his statute is mandatory and ... the district court [does] not have the authority to circumvent the hospitalization.").

189. United States v. Sherman, 722 F. Supp. 504, 505-06 (N.D. Ill. 1989) (noting that the court had no power to order the defendant's placement, but recommending that the Attorney General consider the phrase "hospitalize in a suitable facility" to mean a placement that would give the defendant the treatment he needed to become competent: outpatient care). 
statutes from inpatient-required to inpatient-discretionary in recent years. ${ }^{190}$ In 1972, thirty-two states mandated inpatient treatment upon a finding of incompetence, ${ }^{191}$ compared to only nine jurisdictions today (twelve, including those states that mandate inpatient treatment for felony defendants). And these statutes stand on the weakest constitutional grounds. Indeed, during the editing of this Article, the Georgia Supreme Court held that its statute, which mandated commitment of defendants found incompetent and accused of felonies or violent crimes, was unconstitutional as applied to the defendant because it did not consider his individual circumstances. ${ }^{192}$

Yet mandatory-commitment statutes remain in effect in twelve states-over twenty percent of jurisdictions - and are the kind of statutes most in need of amendment to allow for outpatient restoration programs.

\section{Discretionary Inpatient Statutes}

However, even those states that have moved to a discretionary inpatient commitment regime- - with statutes that say a court "may" commit a defendant rather than "shall" commit him-have not much moved the needle on placing defendants in outpatient programs. Many courts still default to inpatient treatment, even if the statute does not mandate that result. ${ }^{193}$ One survey of state mental health directors found that outpatient treatment is rarely used, even in states with an outpatient option. ${ }^{194}$

At least part of the reason for this problem is the lack of state-run outpatient programs for criminal defendants. For example, Washington allows for outpatient treatment in its competence restoration statute. ${ }^{195}$ But the state has no formal outpatient program, and competency restoration occurs only in the state's two forensic hospitals. ${ }^{196}$ Of the forty-two states that allow for outpatient competence restoration, twenty-three have no state-run outpatient restoration program for

190. For example, D.C. amended its statute in 2004 to allow for treatment in either an inpatient or outpatient setting. See Incompetent Defendants Criminal Commitment Act of 2004, 52 D.C. Reg. 2015, $\S 105$ (May 24, 2005).

191. Robert D. Miller, Hospitalization of Criminal Defendants for Evaluation of Competence to Stand Trial or for Restoration of Competence: Clinical and Legal Issues, 21 BEHAV. SCI. \& L. 369, 381 (2003).

192. McGouirk v. State, 815 S.E.2d 825, 828 (Ga. 2018) ("Neither the crime of which a defendant is accused-a crime of which he must constitutionally be presumed innocent-nor the finding of incompetency to stand trial is itself a sufficient ground to detain a citizen." (quoting Carr v. State, 815 S.E.2d 903, 915 (Ga. 2018))).

193. See Gowensmith et al., supra note 18, at 295 ("Competency restoration typically occurs in state hospitals.").

194. Miller, supra note 191, at 384 ("Despite the availability of outpatient treatment, few states utilize it very often. Eight directors reported that they did not know how frequent outpatient treatment was; 16 reported that no outpatient treatment is done. Eleven directors reported that $5 \%$ or fewer restorations were done on an outpatient basis, and only three directors reported more than 5\%.").

195. WASH. Rev. Code ANN. \$10.77.086 (West 2015).

196. WA REPORT, supra note 18, at 26 ("Competency restoration appears to begin and end at the two state hospitals."). 
criminal defendants. ${ }^{197}$ In those states, outpatient competence restoration is available in theory, but usually not in practice.

Yet even if all states suddenly adopted robust outpatient competence restoration programs, most inpatient-discretionary statutes would still be in dire need of amendment because the criteria for outpatient treatment are either nonexistent or uncertain and irrelevant. When dealing with a stigmatized population such as individuals with mental illness, nebulous standards allow judges to import biases and misunderstandings, which often results in commitment to inpatient facilities.

I outline this problem in the statutes described below, which fall into one of two categories: (a) no guidance for when outpatient treatment would be appropriate, or (b) ineffective criteria for assessing which defendants qualify for outpatient care.

\section{a. No Guidance on Placement of Defendant}

A minority of inpatient-discretionary statutes provide no criteria whatsoever on the placement of the defendant for treatment. Such language is an improvement over the mandatory-commitment statutes because it allows for outpatient treatment, but the lack of guidance as to which placement is appropriate allows sanist biases to drive judicial decisionmaking. Delaware, for example, mentions no outpatient option at all, stating only that courts "may order" the defendant to a state facility to be confined and treated. ${ }^{198}$ The use of "may" rather than "shall" indicates that the door is open to alternatives, such as placement in the community. But the default remains inpatient treatment, and there is little indication that courts in Delaware will order competence restoration in any setting other than a state hospital.

Most inpatient-discretionary statutes are more explicit; they go beyond simply stating that a court "may" place a defendant in inpatient care and explicitly note that defendants can be treated in the community. But several states simply make both inpatient and outpatient options available to the judge, and provide no guidance as to which defendants require each type of treatment. ${ }^{199}$

197. See supra note 18 .

198. Del. CodE ANN. tit. 11, § 404(a) (West 2012) (“[T]the court may order the accused person to be confined and treated in the Delaware Psychiatric Center until the accused person is capable of standing trial."); see also N.Y. CRIM. PROC. LAW § 730.40(1) (McKinney 2013) (“[S]uch court must issue a temporary order of observation committing him or her to the custody of the commissioner for care and treatment in an appropriate institution or, upon the consent of the district attorney, committing him or her to the custody of the commissioner for care and treatment on an out-patient basis ...."); N.D. CENT. CODE ANN. § 12.1-04-08(2) (West 2013) ("The court may at any time make a referral for other appropriate services, treatment, or civil commitment.").

199. Cal. Penal Code $§ 1370(a)(1)(B)(i)$ (West 2018); Conn. Gen. Stat. Ann. § 54-56d (West 2016) ("[T]he court shall order the placement, on either an inpatient or an outpatient basis, which the court finds is the least restrictive placement appropriate and available to restore competency."); GA. CODE ANN. § 17-7-130(c)(3) (West 2017) ("[I]f the accused is charged with a misdemeanor offense or a nonviolent offense, the court shall retain jurisdiction over the accused but may, in its discretion, allow continued treatment to be done on an outpatient basis by the department."); 725 ILl. COMP. STAT. ANN. 5/104-17(b) (West 2018) ("If the defendant's disability is mental, the court may order him placed for treatment in the custody of the Department of Human Services, or the court may order him placed in the 
California provides one example of this type of statute. The court must "order that the mentally incompetent defendant be delivered by the sheriff to a State Department of State Hospitals facility, . . . or to any other available public or private treatment facility, . . . or placed on outpatient status." 200 It then carves out categories for accused sex offenders and those accused of "violent felonies," and requires they be placed in inpatient care unless the defendant would not pose a health and safety risk to others. ${ }^{201}$ But for defendants who fall outside those categories, guidance is in short supply. The only requirement is that the "community program director" evaluate the defendant and recommend inpatient or outpatient treatment. ${ }^{202}$ The statute itself provides no criteria for placement.

Virginia follows a similar course:

[T] he court shall order that the defendant receive treatment to restore his competency on an outpatient basis or, if the court specifically finds that the defendant requires inpatient hospital treatment, at a hospital designated by the Commissioner of Behavioral Health and Developmental Services as appropriate for treatment of persons under criminal charge. ${ }^{203}$

This statute is one of the few that default to outpatient treatment, which is an improvement over those of many states. But the statute leaves unsaid what factors would be considered for the specific finding that the defendant requires inpatient care.

The eight other states that fall into this category-Connecticut, Georgia, Illinois, Maine, Mississippi, Oklahoma, Washington, and West Virginia—use a

custody of any other appropriate public or private mental health facility or treatment program which has agreed to provide treatment to the defendant."); ME. REV. STAT. ANN. tit. 15, § 101-D (2016) ("[T]he court . . . may either . . . [c]ommit the defendant to the custody of the Commissioner of Health and Human Services for placement in an appropriate program for observation, care and treatment of people with mental illness ... [ [which] may be in an institution for the care and treatment of people with mental illness, ... a an intensive outpatient treatment program or any program specifically approved by the court."); OKLA. STAT. ANN. tit. 22, § 1175.7(B) (West 2015) ("The proposed treatment may be either inpatient or outpatient care depending on the facilities and resources available to the court and the type of disability sought to be corrected by the court's order."); VA. CODE ANN. § 19.2-169.2 (West 2017) ("[T]he court shall order that the defendant receive treatment . . . on an outpatient basis or, if the court specifically finds that the defendant requires inpatient hospital treatment, at a hospital ...."); WASH. REV. CodE ANN. \$10.77.086 (West 2015) (“[T]he court: (A) Shall commit the defendant to the custody of the secretary who shall place such defendant in an appropriate facility of the department for evaluation and treatment; or (B) May alternatively order the defendant to undergo evaluation and treatment at some other facility or provider as determined by the department . ..."); W. VA. CODE ANN. $\S 27-6 \mathrm{~A}-3$ (f) (West 2007) ("If at any point in the proceedings the defendant is found not competent to stand trial and is found substantially likely to attain competency, the court of record shall ... make further findings as to whether the defendant requires, in order to attain competency, inpatient management in a mental health facility."); MISS. R. CRIM. P. 12.5(d) ("If the court finds that the defendant is incompetent to stand trial, then the court may commit the defendant to the Mississippi State Hospital, other appropriate mental health facility, or other place of treatment, either inpatient or outpatient ....").

200. CAL. PEnAl Code $\S 1370(a)(1)(B)(i)$.

201. Id. $\S 1370(\mathrm{a})(1)(\mathrm{B})(\mathrm{ii})-(\mathrm{iii}),(\mathrm{a})(1)(\mathrm{F})$.

202. Id. $\S 1370(\mathrm{a})(2)(\mathrm{A})$.

203. VA. CodE ANN. $§ 19.2-169.2(A)$. 
hodgepodge of language. ${ }^{204}$ Yet none guide or restrain a court deciding the placement of a defendant found incompetent. This anything-goes approach inevitably allows sanist bias to infiltrate decisionmaking. ${ }^{205}$

\section{b. Ineffective Criteria for Placement of Defendant}

Most inpatient-discretionary states do provide some criteria for categorizing a defendant as inpatient or outpatient. ${ }^{206}$ But these criteria often ask courts to place a defendant on the basis of her "dangerousness,"207 an assessment that usually sets a higher bar for the release of a defendant found incompetent than the criteria that apply to competent defendants. For example, a court in Arkansas "may" release the incompetent defendant "if the court is satisfied the defendant may be released without danger to himself or herself or to the person or property of another." ${ }^{208}$ A Maryland court may set bail for the same defendant when it finds he "is not dangerous ... to self or the person or property of others." 209

One problem with this language: pretrial release statutes in these states also assess the risk to public safety posed by a particular competent defendant. Yet none of these statutes include language requiring a court to find a competent

204. See supra note 199.

205. See supra Part II.

206. Ariz. Rev. Stat. AnN. § 13-4512(D) (2005); Ark. Code AnN. § 5-2-310(a)(1)(B) (West 2017); D.C. Code $\S 24-531.05$ (a) (2012); Haw. Rev. Stat. ANn. § 704-406(1) (West 2016); IND. Code ANn. § 35-36-3-1(b) (West 2018); Iowa Code Ann. § 812.6 (West 2014); La. Code Crim. Proc. AnN. art. 648 (2017); Md. Code AnN., Crim. Proc. § 3-106 (West 2018); Mich. Comp. Laws Ann. § 330.2032(3) (West 2018); Nev. Rev. Stat. AnN. § 178.425 (West 2017); N.J. Stat. AnN. § 2C:4-6(b) (West 1999); N.M. Stat. AnN. § 31-9-1.2 (1999); Ohio Rev. Code Ann. § 2945.38(B)(1)(b) (West 2016); Or. Rev. Stat. AnN. § 161.370(2) (West 2018); R.I. Gen. Laws AnN. § 40.1-5.3-3(i) (West 2012); Tenn. Code Ann. § 33-7-301(b)(5) (West 2015); Tex. Code Crim. Proc. AnN. art. 46B.072 (West 2017); Ala. R. CRIM. P. 11.6; Fla. R. CRIM. P. 3.212(c)(3).

207. Ark. Code AnN. § 5-2-310(a)(1)(B); Haw. Rev. Stat. Ann. § 704-406(1) ("If the court is satisfied that the defendant may be released on conditions without danger to the defendant or to another or risk of substantial danger to property of others, the court shall order the defendant's release ...."); IowA CODE ANN. § 812.6(1) ("If the court finds the defendant does not pose a danger to the public peace and safety, is otherwise qualified for pretrial release, and is willing to cooperate with treatment, the court shall order, as a condition of pretrial release, that the defendant obtain mental health treatment designed to restore the defendant to competency."); LA. CODE CRIM. Proc. ANN. art. 648(A)(1) ("[I]f the person . . . is considered by the court to be unlikely to commit crimes of violence, then the court may order outpatient care and treatment ....”); MD. Code AnN., CRIM. Proc. § 3-106; Nev. Rev. STAT. AnN. § 178.425(3) (“If the court finds the defendant incompetent but not dangerous to himself or herself or to society, . . the judge shall order the defendant to report to the Administrator or the Administrator's designee as an outpatient for treatment ...."); N.J. STAT. ANN. § 2C:4-6(b) ("[T] he court may commit him to the custody of the Commissioner of Human Services to be placed in an appropriate institution if it is found that the defendant is so dangerous to himself or others as to require institutionalization, or it shall proceed to determine whether placement in an out-patient setting or release is appropriate ...."); TEX. CODE CRIM. PROC. ANN. art. 46B.072(a-1)(1), (2) ("II]f the court determines that a defendant . . . is not a danger to others and may be safely treated on an outpatient basis ... the court . . . may release on bail a defendant found incompetent to stand trial with respect to an offense punishable as a felony . . and ... shall release on bail a defendant found incompetent to stand trial with respect to an offense punishable as a Class A misdemeanor ....").

208. ARK. Code AnN. § 5-2-310(a)(1)(B).

209. Md. Code Ann., Crim. Proc. § 3-106(a). 
defendant is "not dangerous" before release. ${ }^{210}$ Thus, in these states, the hurdle for pretrial release is significantly higher to mount for defendants found incompetent than for competent defendants.

Several of these states do not mention dangerousness at all in their pretrial release statutes, instead using proxies to assess the likelihood a defendant will appear for court hearings or commit a crime while released. ${ }^{211}$ Arkansas is one such state. Judges there must look to the defendant's employment status, prior criminal record, and the nature of the current charge, among other criteria, when making their pretrial release decisions. ${ }^{212}$ Nowhere is the defendant's general "dangerousness" mentioned; only a defendant found incompetent must meet that nebulous standard.

Other states do explicitly assess the defendant's "dangerousness" in their pretrial release statutes. ${ }^{213}$ Yet even in these states, defendants found incompetent must often clear a higher bar than all other defendants. Courts in Hawaii, for example, can deny bail if they find there "is a serious risk that the person poses a danger to any person or the community." ${ }^{214}$ But they only apply this criteria if the defendant is accused of a "serious crime," 215 meaning any crime with a penalty of five years or more. ${ }^{216}$ Defendants not accused of serious crimes are presumptively bailable. ${ }^{217}$ Jamycheal Mitchell, the defendant who stole a Mountain Dew and allegedly starved in his jail cell, ${ }^{218}$ would have been eligible for release under this standard.

The Hawaii pretrial release statute is easier to satisfy than the competence restoration statute in a second way: it does not require courts to find an absence of danger. Under the pretrial release language, courts must find that a defendant poses a "serious risk" of danger to any person or the community. ${ }^{219}$ Under the competence restoration statute, the court must satisfy itself that "the defendant may be released on conditions without danger to the defendant or to another." ${ }^{220}$ For Jamycheal Mitchell to be released under this standard, the court would have had to find the negative-his lack of dangerousness. Defendants

210. See Ala. Code $\S \S 15-13-3,-4$ (2018); Haw. Rev. Stat. Ann. § 804-3 (West 2018); Iowa Code AnN. $\$ 811.1$ (West 2013); LA. Code Crim. Proc. AnN. arts. 313, 316 (2017); Md. Code AnN., Crim. Proc. § 5-101 (West 2013); Nev. Rev. Stat. AnN. §§ 178.484, .4851, .4853 (West 2017); TeX. CodE Crim. Proc. AnN. art. 17.03 (West 2017); ArK. R. CRIM. P. 8.5.

211. Ala. Code $\S$ 15-13-3, -4; Iowa Code Ann. § 811.1; Md. Code AnN., Crim. Proc. § 5-101; Tex. Code Crim. Proc. Ann. art. 17.03; Ark. R. Crim. P. 8.5.

212. ARK. R. CRIM. P. 8.5(b).

213. See Haw. Rev. Stat. Ann. § 804-3; La. Code Crim. Proc. AnN. arts. 313, 316; Nev. Rev. STAT. ANN. $\S \S 178.484, .4851, .4853$.

214. Haw. Rev. Stat. AnN. § 804-3(b)(3).

215. Id. $\$ 804-3(\mathrm{a}),(\mathrm{b})$.

216. Id. $\$ 706-660$.

217. Id. § 804-3(b).

218. See supra notes $1-4$ and accompanying text.

219. See Haw. Rev. Stat. AnN. § 804-3(b).

220. Id. § 704-406(1). 
found incompetent thus have a tougher row to hoe before they are released. ${ }^{221}$

In addition, the "dangerousness" criterion is nebulous, which allows for the import of bias. Indeed, criteria like "dangerousness" are problematic not only because they impose a higher standard than pretrial release statutes, but also because they inject uncertainty into competence restoration statutes. There is little agreement among courts and mental health professionals as to what qualifies a person as dangerous. Any assessment of dangerousness must look to the magnitude of the harm (Does the defendant pose a risk of murdering another? Punching another? Threatening another?) as well as the likelihood that the danger will actually occur (Is it certain that this harm will occur? Will it only happen if the defendant is under stress or comes in contact with a certain person? Will it happen immediately? In three months? In two years?). ${ }^{222}$ Most courts have not tackled these questions. ${ }^{223}$

Moreover, uncertainty abounds when courts or psychiatrists attempt to predict the future - and the dangerousness predictions of mental health professionals are notoriously unreliable. Studies have found that expert testimony that relies on the clinical model, that is, a mental health professional assessing the dangerousness of an individual witness through "whatever information the individual clinician deemed pertinent," is inaccurate about half the time. ${ }^{224}$ One review of the literature found three central facts to be true: "(a) Mental health practitioners inaccurately make future violence predictions, (b) mental health practitioners lack training in making violence predictions, and (c) mental health practitioners' dangerousness predictions are biased by their reliance on a number of cognitive heuristics, which causes them to overestimate rates of future violence."225

Judges have recognized that this vast amount of uncertainty gives them enormous discretion on the question of a defendant's danger. As one jurist noted, his decisions on whether an individual posed a threat of harm "were inevitably based

221. Cf. Vieth v. Jubelirer, 541 U.S. 267, 311 (2004) (Kennedy, J., concurring) (“[P]roving a negative is a challenge in any context.”); Elkins v. United States, 364 U.S. 206, 218 (1960) (“[A]s a practical matter it is never easy to prove a negative ....").

222. See, e.g., William M. Brooks, The Tail Still Wags the Dog: The Pervasive and Inappropriate Influence by the Psychiatric Profession on the Civil Commitment Process, 86 N.D. L. REv. 259, 292-93 (2010).

223. Id. at 293.

224. Christopher Slobogin, Dangerousness and Expertise Redux, 56 EMORY L.J. 275, 283, 291 (2006) (noting additionally that success rates can only be fairly assessed by comparing the likelihood of accurate prediction to chance, and that a fifty percent accuracy rate could be far more accurate than a random assignment).

225. Daniel A. Krauss \& Bruce D. Sales, The Effects of Clinical and Scientific Expert Testimony on Juror Decision Making in Capital Sentencing, 7 Psychol. PuB. POL'Y \& L. 267, 280-81 (2001). More recent actuarial methodologies have resulted in better predictions of dangerousness, but nowhere near perfection. The testimony of a clinician, relying on an interview and assessment of the individual patient, is usually only correct about half the time, whereas the actuarial models, which rely on assessing the presence of a series of variables, range from around sixty to eighty percent accuracy. This is still a rate of false positives twenty percent of the time, at best. See Slobogin, supra note 224, at 283-93. 
upon my personal values and standards."226

\section{An Outpatient Competence Restoration Model}

Whether inpatient-required or inpatient-discretionary, competence restoration statutes achieve nearly the same end: inpatient commitment in the vast majority of cases. This is because many discretionary statutes either provide no guidance on competence restoration placement or use criteria like "dangerousness" that implicate a judge's "personal values and standards." 227 In a system suffused with sanism, such untethered decisionmaking will lead to the overcommitment of defendants to inpatient facilities. To counterbalance this tendency, a competence restoration statute must reduce discretion and restrain a judge. It must become more like a rule and less like a standard. ${ }^{228}$

Let's back up to discuss standards and rules, ${ }^{229}$ and why a rule is a better approach when bias is in play. A legal directive is rule-like "when it binds a decisionmaker" to a particular outcome when certain triggering facts are present. ${ }^{230}$ One benefit of this form of legal directive is that it constrains arbitrariness, which allows for invalid criteria such as bias to seep into a decision. ${ }^{231}$

The main drawback to a rule-based approach is that rules can be both over- and under-inclusive, thereby not achieving the underlying goal of the rule in all circumstances. ${ }^{232}$ For example, a rule may bar individuals under eighteen from voting under the assumption that younger people do not have the decisionmaking prowess to adequately exercise the voting right. But such a rule both bars exceptionally mature and thoughtful young people from voting, and also allows exceptionally immature and unthoughtful thirty-year-olds to vote.

Standards, ideally, avoid these errors of under- and over-inclusiveness by giving the decisionmaker more discretion and allowing her to take all relevant factors into account. ${ }^{233}$ This flexibility can prevent injustices from occurring-for instance, by allowing the exceptionally mature fifteen-year-old to vote.

Yet standards contain their own problems-most notably, uncertainty of outcomes and opportunity for decisions to be based on individual bias. ${ }^{234}$ For

226. Brooks, supra note 222, at 295 (quoting Judge Sees Lack of Guidelines for Committing Mental Patients, N.Y. L.J., Nov. 27, 1987, at 1).

227. Id.

228. See, e.g., Kathleen M. Sullivan, Foreward: The Justices of Rules and Standards, 106 HARV. L. REV. 22, 62-66 (1992) (presenting arguments why rules might be preferable to standards).

229. As many scholars have noted, most laws do not fall into a "rules" or "standards" category. Instead, most laws sit on the spectrum between rule and standard, with some espousing rule-like qualities and others more standard-like. And, over time and through the analogical reasoning deployed in many court decisions, one may evolve to look more like the other. See, e.g., Wilson Huhn, The Stages of Legal Reasoning: Formalism, Analogy, and Realism, 48 VILL. L. REV. 305, 377-79 (2003).

230. Sullivan, supra note 228 , at 58 .

231. Duncan Kennedy, Form and Substance in Private Law Adjudication, 89 HARV. L. Rev. 1685, 1688 (1976).

232. See Sullivan, supra note 228 , at 58.

233. Id. at $58-59$.

234. Id. at 58 n.236. 
example, a standards-based approach to voting eligibility would allow any individual with sufficient maturity and intellect to vote, rather than rely on an age cut-off. But different judges will have vastly different ideas of what sufficient maturity and intellect would be. The same person granted voting rights by one judge might be denied them by another. Moreover, some judges may believeconsciously or not - that any individual who holds radical left-wing or right-wing views should not be allowed to vote, even if she exhibits indicators of maturity and intellect. A standard like "sufficient maturity and intellect" allows those judges to import these partisan leanings into their decisionmaking.

A stringent rule with well-defined criteria is a more appropriate form of legal directive when a decisionmaker's implicit biases may be the primary drivers of a decision. ${ }^{235}$ As Cass Sunstein has stated:

[Rules] can also counteract something worse: bias, favoritism, or discrimination in the minds of people who decide particular cases. In this way, rules are associated with impartiality, a notion which is captured in the idea that Justice, the goddess, is "blindfolded." Rules are blind to many features of a case that might otherwise be relevant, and that are relevant in some social contexts, or to many things on whose relevance people have great difficulty in agreeingreligion, social class, good or bad looks, height, and so forth. ${ }^{236}$

Add to this list mental illness, one of the most highly stigmatized issues in American society. ${ }^{237}$ A more rule-like competence restoration statute would therefore theoretically cabin judicial discretion and prevent judges from incorporating sanist biases into their decisionmaking.

This prediction assumes, of course, that rules actually constrain more than standards do, which is a hotly debated question beyond the scope of this Article. But all agree that, at the very least, the more rule-like a statute is, the more work a judge must do to justify reaching a decision contrary to the dictates of the rule. ${ }^{238}$ Reasoned consideration is the enemy of unconscious bias, ${ }^{239}$ and even if a more rule-like statute only succeeds in forcing a judge to think about her decisions more carefully, reduction in sanist decisionmaking is the likely result.

What would a more rule-like competence restoration regime look like? Two changes are necessary. First, the statute must align with the state's pretrial release statute and not impose higher and more nebulous barriers to release on non-treatment-related grounds. Second, the statute must require outpatient care if the defendant is eligible for pretrial release, and only allow inpatient care if such treatment is necessary for successful competence restoration.

235. See id.

236. Cass R. Sunstein, Problems with Rules, 83 CALIF. L. Rev. 953, 974 (1995) (citation omitted).

237. See supra Part II.

238. See, e.g., Frederick Schauer, Formalism, 97 YALE L.J. 509, 518-19 (1988).

239. See Jeffrey J. Rachlinski et al., Does Unconscious Racial Bias Affect Trial Judges?, 84 NotRE DAme L. Rev. 1195, 1225 (2009) (“Control of implicit bias requires active, conscious control.”). 


\section{A. ELIMINATING PRETRIAL RELEASE DISPARITIES}

The first step for effective competence restoration statutes is to pair these statutes with their pretrial release counterparts. Surprisingly, few statutes crossreference the incompetence commitment procedure with the pretrial release procedure. As I illustrated above, this imposes higher and more nebulous criteria on defendants found incompetent to stand trial that are inapplicable to other defendants.

This alternate-standard model is problematic in two respects. First, the simple fact that it treats defendants found incompetent differently, and that some statutes require courts to be extra-double-sure that this defendant is not dangerous, triggers a judge's sanist impulses. It implies that these defendants are more dangerous, are more in need of confinement, and, further, that the presumption of release that applies to other defendants does not apply to them. That differential treatment, on its own, leads to more inpatient commitments than are necessary.

Second, in many jurisdictions, the criteria for release of defendants found incompetent are far on the standard end of the spectrum, while the criteria for other defendants have the features of a rule. And the trend for pretrial release statutes is moving toward more rule-like empirical risk assessments. ${ }^{240}$ Incorporating the pretrial release criteria into the competence restoration statute avoids the inequity of holding incompetent defendants before trial on nebulous dangerousness grounds, while assessing and releasing competent defendants using rule-like empirical metrics.

Colorado is an example of a state that has already incorporated the pretrial release statute into its competence restoration scheme. Its competence restoration statute says that "[i]f the defendant is in custody, the court may release the defendant on bond upon compliance with the standards and procedures for such release prescribed by statute and by the Colorado rules of criminal procedure."241

The state's pretrial release statute then adopts as its goals the reasonable assurance of the defendant's appearance at trial and the safety of any person or the community. It requires courts to use, when available, "an empirically developed risk assessment instrument designed to improve pretrial release decisions by providing to the court information that classifies a person in custody based upon predicted level of risk of pretrial failure." 242 As Colorado implements risk assessment instruments to determine pretrial release, defendants found incompetent will also benefit from the change.

240. See Lauryn P. Gouldin, Disentangling Flight Risk from Dangerousness, 2016 BYU L. REV. 837 , 842 (noting that pretrial risk assessments promise "to make pretrial decision-making less subjective, to improve risk prediction, and to alleviate pressure on judges to err on the side of (over)detention"); see also id. at 841 (stating that ten percent of jurisdictions have adopted an "empirically-based risk assessment tool, and that number continues to rise").

241. Colo. Rev. Stat. AnN. § 16-8.5-111(2)(a) (West 2017).

242. Id. § 16-4-103(3)(a)-(b). 
Few other states explicitly connect pretrial release statutes and incompetence statutes. ${ }^{243}$ The benefit to doing so is that it guarantees the same standards are applied to incompetent and competent defendants. It eliminates the prospect of a defendant, otherwise eligible for pretrial release, being held in confinement because the state mandates inpatient treatment for findings of incompetence. It also cabins judicial discretion for those competence restoration statutes where release criteria are nonexistent or grounded in standards like "not dangerous." And as rule-like empirical metrics for assessing risk grow more popular and become more incorporated into pretrial release decisions in general, incompetent defendants reap the benefits of that change, just as competent defendants do. ${ }^{244}$

\section{B. IMPOSING CONCRETE CRITERIA FOR INPATIENT TREATMENT}

Although aligning pretrial release statutes with competence restoration statutes eliminates differential treatment on the basis of vague criteria such as "dangerousness," an effective competence restoration statute must address one inquiry inapplicable to a competent defendant: the likelihood of treatment success in the community. A defendant found incompetent, who is otherwise eligible for release under the normal pretrial criteria, should be referred for inpatient treatment if evidence shows that outpatient treatment will not work. But here, too, adoption of a rule-like statute would curb a judge's tendency toward inpatient commitment-a sanist impulse that treatment in a hospital is almost always the best option-and thus would reserve those hospital beds for the defendants who truly need them.

This aspect of the statute should contain two parts. First, the statute should default to outpatient treatment. Starting with the assumption that a defendant will be placed in outpatient treatment unless some specific reason justifies inpatient care constrains a judge's ability to commit defendants based on little more than intuition. The second part of the statute would provide exceptions detailing when inpatient care is necessary. These exceptions must only assess the likelihood of treatment success, not dangerousness or safety, as those questions would have already been determined through the pretrial release assessment. And they must be rule-like, which means they provide concrete triggering facts that bind a decisionmaker to respond in a particular way. ${ }^{245}$ Because the goal is to keep these circumstances the exception rather than the rule, they should be narrowly drawn to capture only those defendants who either have a demonstrated history of failure in community treatment or have some hallmark of being unable to follow a treatment regimen outside of a structured environment.

A rule that satisfies these goals may look something like this: If a defendant is otherwise eligible for pretrial release, he or she will be placed in outpatient treatment to restore his or her competence, except the court may place the defendant

243. Illinois also connects its competence restoration and pretrial release statutes. See 725 ILL. CoMP. StAT. AnN. 5/104-17 (West 2018).

244. See supra note 240 , at $841-42$.

245. Sullivan, supra note 228 , at 58 ("A legal directive is "rule'-like when it binds a decisionmaker to respond in a determinate way to the presence of delimited triggering facts."). 
in inpatient care if (1) the defendant is unable to care for himself and is in need of constant supervision and support, or (2) the defendant has shown no improvement in outpatient care after a period of thirty days.

Each of these categories captures a specific circumstance under which a defendant would be unlikely to succeed in outpatient care. The first exception comes from the American Psychiatric Association's recommendations for when a patient with schizophrenia is so ill that he requires hospitalization. ${ }^{246}$ The APA default is treatment in the community, and inpatient care only becomes appropriate when the psychotic symptoms reach a stage where the patient needs a structured environment to function. ${ }^{247}$

The second exception provides an opt-out if outpatient treatment proves unsuccessful. If the defendant has begun outpatient care and is showing no alleviation of symptoms, the court must not be obligated to continue down a path that is not working.

Compare this proposed statute to the American Bar Association's recently adopted Model Standards on competence restoration, ${ }^{248}$ which make some progress in this area but still leave much room for judicial discretion. Those standards prohibit involuntary hospitalization of defendants found incompetent unless "no appropriate treatment alternative is available that is less restrictive than placement in the facility." 249 The benefit to this approach is that it flips the statutes so they default to outpatient treatment.

But the criteria the ABA model standard provides for determining when inpatient treatment is appropriate will do little to offset the judicial inclination to commit defendants found incompetent. Under the model standard, judges have little guidance on what kind of treatment may be "appropriate." As illustrated above, many judges may default to believing that only inpatient treatment is appropriate for those who suffer from psychotic disorders. ${ }^{250}$ Moreover, the consideration of what is "appropriate" is not limited to medical considerations, and a judge may mistakenly believe that a defendant is too dangerous to place in the community. Even if such a defendant would be released under a usual pretrial assessment, a judge could believe that outpatient placement would not be "appropriate." A statute that lays out specific, restoration-based reasons for ordering inpatient treatment will be far more successful in curbing overcommitment to inpatient facilities.

\section{CRITIQUES OF PROPOSED COMPETENCE RESTORATION REGIME}

As I illustrated above, a strict outpatient default with narrow, treatment-based exceptions for hospitalization could substantially curb the judicial tendency to commit defendants found incompetent, thus reducing the time that many

\footnotetext{
246. See AM. PSYCHIATRIC Ass'N, supra note 145, at 54.

247. Id.

248. Criminal Justice Standards on Mental Health (2016).

249. Id. § 7-4.10(a)(iii)(B).

250. See supra Part II.
} 
defendants spend confined while awaiting trial. Yet some critiques of this proposed law are immediately apparent. I attempt to address those critiques in this section.

\section{These Are Not Really Rules}

One possible critique of the proposed statute is that it is not more rule-like at all, and simply replaces one set of standards with another. This criticism can be applied to both the pairing of pretrial release statutes with competence restoration statutes and the specific proposed language of the competence restoration statute. But these criticisms require different responses.

First, if a state's pretrial release criteria remain uncertain and mostly within a judge's unbridled discretion, the general bias against defendants with mental health conditions could still creep into commitment decisions. Some states, for example, ask judges to assess the risk a defendant poses to the safety of himself or others as part of the decision on whether to release him. ${ }^{251}$ Judges could therefore require inpatient commitment based on sanist assumptions about a defendant's dangerousness, exactly the outcome the proposed statute aims to eradicate.

Two responses to this critique are in order. First, states are unequivocally moving in the direction of empirical risk assessments. ${ }^{252}$ As that process continues, defendants found incompetent to stand trial, like all defendants, will be subject to considerations such as whether they own a cell phone and have a job, and the nature of the charge, rather than abstract concepts of danger. Second, even if a state retained language such as "dangerousness" in its pretrial release statute, a change to pair that statute with the competence restoration framework would, at the very least, avoid the specter of courts double-counting dangerousness. By requiring courts to find that a defendant is not dangerous as part of the competence restoration calculus, the statute triggers judicial bias in a way that it might not if judges looked to that consideration for every defendant. Moreover, requiring courts to look to the pretrial release statutes would undoubtedly be an improvement in mandatory-commitment jurisdictions, which currently require inpatient treatment in all circumstances.

A further critique takes aim at the value of the risk assessments themselves. The proposed statute assumes that risk assessment is a more objective metric that will avoid bias, but some scholars have shown that bias may be baked into the empirical model as well. Empirical metrics may provide the veneer of objectivity without eradicating bias. ${ }^{253}$

This criticism is well-taken, but it also misses the point, at least as far as this Article goes. Pairing the fortunes of defendants found incompetent and defendants found competent eliminates the possibility of differential treatment on the

251. E.g., Haw. Rev. Stat. AnN. § 804-3(b)(3) (West 2018).

252. See supra note 240 , at 841 .

253. See, e.g., Melissa Hamilton, Risk-Needs Assessment: Constitutional and Ethical Challenges, 52 AM. CRIM. L. Rev. 231, 242-71 (2015); John Monahan, A Jurisprudence of Risk Assessment: Forecasting Harm Among Prisoners, Predators, and Patients, 92 VA. L. Rev. 391, 392-93 (2006). 
basis of irrelevant factors. True, defendants found incompetent may still risk bias from an empirical risk assessment. But there is less space for bias in such an assessment than from a competence restoration statute requiring a court to find the defendant "not dangerous." And it is again an improvement over mandatorycommitment statutes, which allow no defendant found incompetent to be released. Coupling the competence restoration statute and the pretrial release statute at least eliminates the higher bar for defendants found incompetent, and opens the door for future improvements to the metrics, which may also benefit defendants found incompetent.

The second half of the statute-particularly the exceptions to outpatient treatment-is also open to the critique that the exceptions are not pure rules. For example, whether an individual is unable to care for himself is open to interpretation. Yet any rule has standard-like features, and standards often have rule-like features; no legal directive is purely one or the other. ${ }^{254}$ The changes suggested here move the statute much further into rule territory than the status quo, thus narrowing the potential for sanist impulses to govern decisionmaking.

Another potential critique is that the move towards rule-like language risks underinclusivity; defendants may be unlikely to be successfully treated in the community for reasons other than those listed in the exceptions. In those cases, a judge would be unable to order inpatient treatment even if the defendant sorely needs it.

This critique, however, assumes that judges have perfect foresight as to who will respond to treatment in the community. They do not. ${ }^{255}$ A judge's conviction that a defendant without a history of difficulties in treatment will not succeed in outpatient care may reflect little more than the sanist biases outlined above. And although my proposed statute risks putting an individual who will not comply with a treatment protocol into the community, the remedy for such an infraction would be to revoke his release and place him in inpatient care. The status quo commits to inpatient treatment individuals who could be restored to competence in the community, depriving them of their freedom and perhaps harming them physically and mentally, with no avenue for correcting that mistake. The harms of the current situation seem far higher than any risk of future mistaken placement.

\section{No Legislature Would Pass These Amendments}

Another critique is a practical one: that the chance of any legislature passing these kinds of amendments is slim. Legislators are not immune to sanist prejudices and likely fear the same outcome as judges: a released defendant who commits a horrific crime.

254. See, e.g., Margaret Jane Radin, Presumptive Positivism and Trivial Cases, 14 HARV. J.L. \& PuB. POL'Y 823, 828-32 (1991) (explaining that rules and standards are theoretical endpoints on a continuum rather than sharply distinct categories).

255. Cf. supra Section II.A (noting the difficulty of predicting the future in dangerousness determinations). 
Yet even if the arguments above are not enough to override a sanist impulse, compelling additional reasons exist for legislative action on this front. First, the move toward outpatient care would create significant cost savings. A state would save thousands of dollars for each patient it is able to move from inpatient facilities to community treatment. ${ }^{256}$ Second, states are currently under assault from lawsuits alleging that these defendants' constitutional rights are being violated by their lengthy stays in jails while awaiting transfer to inpatient facilities. ${ }^{257}$ And they are losing. For example, Washington state is under a court order to decrease its wait times to seven days. ${ }^{258}$ It has failed to do so and paid $\$ 12$ million in fines for noncompliance. ${ }^{259}$ The Georgia Supreme Court recently found its mandatorycommitment statute unconstitutional on due process grounds. ${ }^{260}$ Other lawsuits are likely not far behind. ${ }^{261}$

The battles over mental health detention are costly, both financially and in terms of the state's public image. These kinds of cases could compel legislatures to preemptively require outpatient care before a court order forces them to do it.

\section{There Are Better Alternatives}

This Article has proposed statutory amendments to allow and encourage outpatient treatment of defendants living with mental illness as a new tool to alleviate the crisis of overcrowding in forensic facilities and to reduce the number of such defendants held in pretrial detention. But it is not the only tool, nor is it the best tool in all circumstances. Instead, this option should be seen as one of many levers a judge could push when faced with a defendant found incompetent who is accused of a crime that, in a competent defendant, would likely result in pretrial release.

256. See WA REPORT, supra note 18 , at 29.

257. See, e.g., Or. Advocacy Ctr. v. Mink, 322 F.3d 1101, 1122 (9th Cir. 2003) ("Holding incapacitated criminal defendants in jail for weeks or months violates their due process rights because the nature and duration of their incarceration bear no reasonable relation to the evaluative and restorative purposes for which courts commit those individuals."); Terry ex rel. Terry v. Hill, 232 F. Supp. 2d 934, 943-44 (E.D. Ark. 2002) ("The lengthy and indefinite periods of incarceration, without any legal adjudication of the crime charged, caused by the lack of space at [the state hospital], is not related to any legitimate goal, is purposeless and cannot be constitutionally inflicted upon the members of the class.").

258. Trueblood v. Wash. Dep't of Soc. \& Health Servs., 101 F. Supp. 3d 1010, 1012 (W.D. Wash. 2015).

259. Press Release, ACLU Wash., Fines Paid by the State of Washington for Failure to Comply with Court Orders Given to Programs That Keep People with Mental Illness Out of Jail (Mar. 22, 2017), https:// www.aclu-wa.org/news/fines-paid-state-washington-failure-comply-court-orders-given-programs-keeppeople-mental [https://perma.cc/3GZS-QLPF].

260. See McGouirk v. State, 815 S.E.2d 825, 827-28 (Ga. 2018).

261. The cases that have been filed thus far have mainly been grounded in substantive due process arguments. But one scholar has argued that requiring inpatient commitment also violates the Americans with Disabilities Act, as interpreted by Olmstead v. L.C., 527 U.S. 581 (1999), which required states to provide community-based treatment for people with mental disabilities. See Michael L. Perlin, "For the Misdemeanor Outlaw": The Impact of the ADA on the Institutionalization of Criminal Defendants with Mental Disabilities, 52 ALA. L. REv. 193, 194-95 (2000). 
The specific options available to police, prosecutors, and judges in criminal cases vary by jurisdiction, but every state affords the opportunity to not pursue charges against a defendant. In some cases, it might be best to divert the defendant from the criminal justice system altogether.

For example, several states have instituted special police units trained to deal with individuals in a mental health crisis. These units aim to take individuals with mental illness for treatment rather than arresting them. ${ }^{262}$ Yet this strategy is used mostly for individuals who would be arrested for misdemeanors like disorderly conduct or other low-level crimes; ${ }^{263}$ defendants accused of more serious criminal conduct will usually go through the criminal courts.

Another mechanism growing in popularity is the use of mental health courts. Some jurisdictions have seen great success with this kind of alternate system, which combines the effectiveness of treatment options with the coercive power of the criminal justice system. ${ }^{264}$ Yet competence is often a prerequisite for individuals to be diverted to mental health courts. ${ }^{265}$ Individuals found incompetent may not be eligible for this option and are relegated to the usual criminal process.

These alternatives are helpful for those defendants that fit within the relevant criteria. But there will always be some subset of defendants whose alleged crimes must be prosecuted through the normal criminal justice channels, and it is to this subset of defendants that the proposal made in this Article will be of the most help. What is proposed here is not some method of special treatment. In fact, it is the opposite: to ensure that the same non-sanist decisionmaking that applies to competent defendants also applies to those found incompetent to stand trial.

262. See, e.g., Jenny Gold, Mental Health Cops Help Reweave Social Safety Net in San Antonio, NPR (Aug. 19, 2014, 3:34 AM), https://www.npr.org/sections/health-shots/2014/08/19/338895262/ mental-health-cops-help-reweave-social-safety-net-in-san-antonio [https://perma.cc/KDW8-LDZZ] (highlighting the police department's initiative with "smart justice - -basically, diverting people with serious mental illness out of jail and into treatment instead"); Stephanie O'Neill, Police and the Mentally Ill: LAPD Unit Praised as Model for Nation, 89.3 KPCC (Mar. 9, 2015), https://www.scpr. org/news/2015/03/09/50245/police-and-the-mentally-ill-lapd-unit-praised-as-m/ [https://perma.cc/57YMV7AH].

263. See, e.g., Stephanie Franz \& Randy Borum, Crisis Intervention Teams May Prevent Arrests of People with Mental Illnesses, 12 POLICE PrAC. \& RES. 265, 266 (2011) (noting that the goal of jail diversion programs is to divert "minor offenders" away from incarceration and toward treatment).

264. See generally Virginia Aldigé Hiday et al., Effectiveness of a Short-Term Mental Health Court: Criminal Recidivism One Year Postexit, 37 L. \& Hum. BeHAV. 401 (2013) (studying mental health courts in Washington, D.C. and finding that their results-fewer participants were re-arrested in the year following treatment than similar defendants processed through traditional criminal court—added to the accumulating evidence of the courts' effectiveness).

265. See id. at 402 (noting that D.C. mental health court "accepts competent severely mentally ill arrestees"). 


\section{Conclusion}

Our current system of inpatient competence restoration is badly broken. ${ }^{266}$ Long wait times in jail harm defendants found incompetent, and the mere undertaking of competence restoration causes significant delays in the ultimate resolution of a defendant's case.

Increased use of outpatient treatment would lessen these effects. First, for many individuals, outpatient treatment will be as successful as the inpatient model. Second, for those individuals who do not qualify for outpatient treatment, moving some defendants out of the inpatient system would free up much-needed bed space, thus reducing wait times from their current, torturous lengths.

To fix this problem, state and federal competence restoration statutes must be revised to encourage more outpatient placement. These schemes are deficient in three main respects. First, outpatient treatment is not even a statutory option in many states. Second, nearly every state with an outpatient option leaves it to the discretion of the judge, who "may" place the defendant in outpatient care. This discretion often leads to defendants remaining in jail who would otherwise benefit from outpatient care. Third, even states that provide guidance for the placement of incompetent defendants have labeled ambiguous or irrelevant information as determinative. The end result is that some individuals in every state are subject to detention, but would be better served in the community.

Statutory change is thus required in all jurisdictions. Legislatures should amend their codes to require judges to release defendants otherwise qualified for pretrial release and refer them for outpatient care as a condition of release, unless they fit within a narrow exception for inpatient care. Moving to an "outpatientunless" scheme would immediately increase the population of incompetent defendants treated through outpatient means, thereby easing the backlog for individuals who require inpatient care.

266. See, e.g., Wortzel et al., supra note 105, at 357 ("Physicians, advocates for the mentally ill, proponents of constitutional law, legal and correctional authorities, and champions of basic human rights recognize the unacceptable situation that has resulted from the [incompetent to proceed] crisis."). 